\title{
Asymmetric Total Synthesis and Biological Evaluation of $(+)$-Cycloclavine
}

\author{
Stephanie R. McCabe \\ Peter Wipf* (D) \\ Department of Chemistry, University of Pittsburgh, Pittsburgh, PA \\ 15260, USA \\ pwipf@pitt.edu
}

Published as part of the 50 Years SYNTHESIS - Golden Anniversary Issue
Received: 29.10 .2018

Accepted: 31.10 .2018

Published online: 20.11 .2018

DOI: 10.1055/s-0037-1610395; Art ID: ss-2018-z0728-fa

License terms: $(\subset)(-)$

Abstract The first total synthesis of natural (+)-cycloclavine uses a catalytic asymmetric cyclopropanation of allene, a regiospecific Pdcatalyzed enone formation, and two intramolecular Diels-Alder reactions for indole/indoline annulations. The binding properties of natural (+)- and unnatural (-)-cycloclavine on 16 CNS receptors revealed significant stereospecificity and unique binding profiles in comparison to LSD, psilocin, and DMT. Differential 5-HT affinities, as well as novel sigma- 1 receptor properties bode well for potential therapeutic developments of clavine alkaloid scaffolds.

Key words clavine ergot alkaloids, enantioselective allene cyclopropanation, psychedelics, stereospecific GPCR binding, LSD, psilocin, DMT, 5-HTA, sigma- 1 receptors

While the unique properties of naturally occurring compounds have always fascinated researchers from all branches of Science, the total synthesis of alkaloids currently experiences a remarkable renaissance, motivated by the complex architectures, diverse functionalities, and profound biological and cultural impact of this large family of natural products. ${ }^{1}$ Indole alkaloids, in particular, are attracting significant attention in Chemistry and Medicine. ${ }^{2}$ With the goal to explore both innovative synthetic strategies and new biological applications, we have recently established a program in the total synthesis of ergot alkaloids of the clavine and lysergic acid subclasses (Figure 1). ${ }^{3}$

In 1969, A. Hofmann and co-workers at Sandoz in Basel, Switzerland, reported the isolation of a novel, cyclopropane-containing ergot alkaloid, (+)-cycloclavine, from the seeds of the morning glory Ipomoea hildebrandtii VAT$\mathrm{KE}$, collected in Nairobi, Kenya. ${ }^{4}$ After a latency of almost 40 years, cycloclavine has now become a popular target for organic synthesis, and a number of groups have reported in-
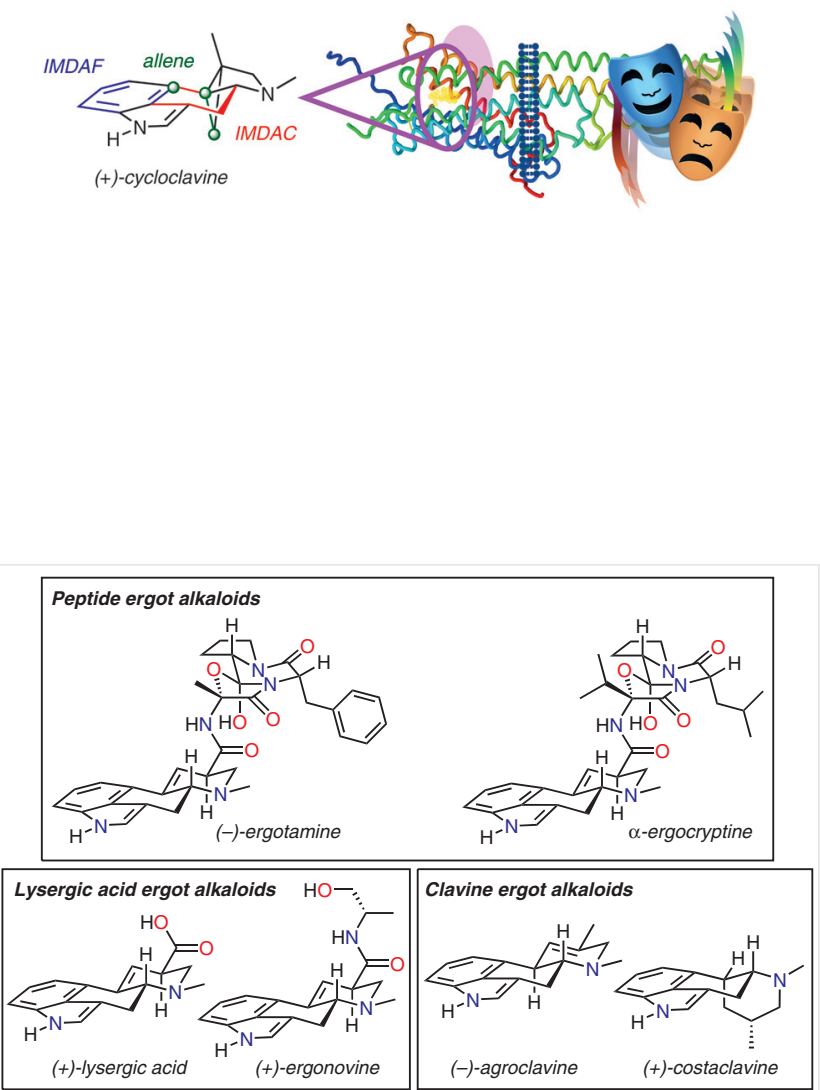

Figure 1 Examples of naturally occurring ergot alkaloids

novative synthetic approaches. In pioneering studies from the group of Szántay, 4-bromo-Uhle's ketone was subjected to an alkylation and intramolecular aldol reaction with 3methylaminopropanoate, and the first synthesis of $( \pm)$-cycloclavine was completed in 2008 by a cyclopropanation of a tetrasubstituted alkene with $\mathrm{CH}_{2} \mathrm{~N}_{2}$ (Scheme 1). ${ }^{5}$ Motivated by our interests in the synthetic and medicinal chemistry of indoles, ${ }^{6}$ the structurally unique indoline-indole scaffold of cycloclavine served as our first ergot alkaloid target. In 2011, we developed an intramolecular $\mathrm{S}_{\mathrm{N}} 2$-displacement and furan Diels-Alder reaction for the formation of the fused pentacyclic ring system and the synthesis of $( \pm)-5-$ epi-cycloclavine. ${ }^{7}$ Subsequently, we modified this approach and used an intramolecular Diels-Alder reaction to a strainactivated methylenecyclopropane for the construction of the indoline segment and the total synthesis of $( \pm)$-cycloclavine (Scheme 1). ${ }^{7}$

In 2014, Brewer and co-workers used a fragmentation and an azomethine ylide 1,3-dipolar cycloaddition to construct racemic cycloclavine (Scheme 2 ). ${ }^{8}$ Cao's group devel- 

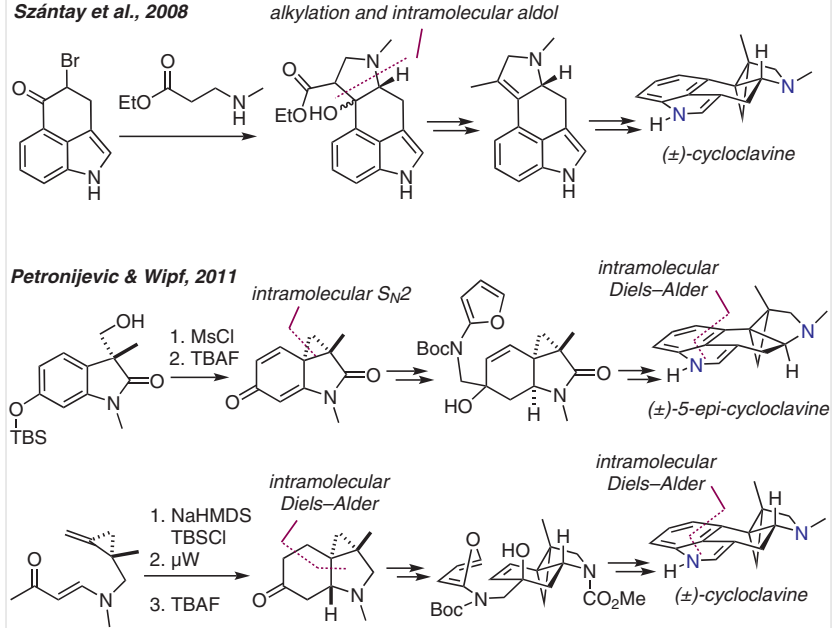

Scheme 1 Early synthetic strategies in the total synthesis of cycloclavines

oped two formal syntheses of racemic cycloclavine and a formal synthesis of $(+)$-cycloclavine starting from substituted indoles and intersecting with the late stage alkene in Szántay's synthesis. ${ }^{9}$

Another formal synthesis of $( \pm)$-cycloclavine that converged with Szántay's approach was accomplished by Netz and Opatz in 2016, utilizing a $\gamma$-alkylation of a pyrrolinone followed by a Heck coupling. ${ }^{10}$

The first asymmetric synthesis of (-)-cycloclavine, the enantiomer of the natural alkaloid, was accomplished by our group in 2017. ${ }^{11}$ Key features of this synthesis were a catalytic asymmetric cyclopropanation of allene, an intramolecular Diels-Alder reaction to methylenecyclopropane (IMDAMC), and an intramolecular Diels-Alder reaction to furan (IMDAF). Subsequently, a formal synthesis of both enantiomers of cycloclavine was realized by Bisai and coworkers based on a D- or L-proline catalyzed $\alpha$-aminoxylation and a Heck coupling (Scheme 2). ${ }^{12}$ Most recently, Dong and co-workers developed a benzyne cycloaddition/alkene carboacylation route to both (-)-5-epi-cycloclavine and (-)-cycloclavine, utilizing a ring-enlargement of a benzocyclobutenone intermediate as a key reaction. ${ }^{13}$ The impressive publication surge and the diverse strategies of these synthetic approaches illustrate the high level of current interest in architecturally novel alkaloid natural products. We now report the details of the first enantioselective total synthesis of (+)-cycloclavine.

Our retrosynthetic analysis is summarized in Scheme 3. In analogy to our route to (-)-cycloclavine, ${ }^{11}$ we selected an asymmetric rhodium-catalyzed cyclopropanation of allene with a diazopropanoate active ester, followed by an aminolysis with 4-(methylamino)but-3-en-2-one, for the assembly of the key precursor for the IMDAMC reaction. After installing the enone in the six-membered ring by a DiaoStahl ketone dehydrogenation, ${ }^{14}$ the thermally removable Tempoc group for amine protection ${ }^{15}$ would be used to stabilize an aminomethyllithium reagent and favor enone 1,2addition versus lactam ring opening. The final indole ring fusion was envisioned to be accomplished by the IMDAF cycloaddition. ${ }^{6 \mathrm{~b}, \mathrm{~d}, \mathrm{f}, 7,16}$

\section{Biographical Sketches}
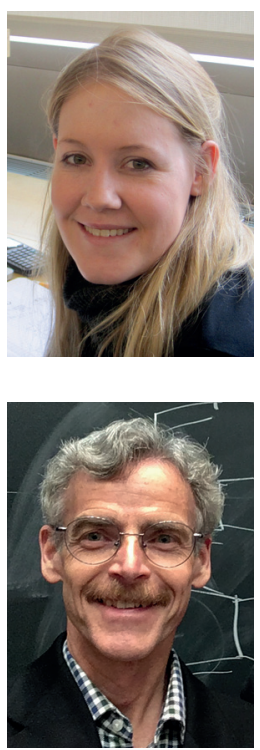

Stephanie R. McCabe received her B.Sc. (Honours) in 2012 from the Australian National University, conducting re- search under the supervision of Professor Martin Banwell. In 2018, she obtained her Ph.D. in the Wipf group at the University of Pittsburgh. Her research interests centered on natural product total synthesis.
Peter Wipf received his Ph.D. in 1987 from the University of Zürich under the direction of Professor Heinz Heimgartner. He then joined the laboratory of Professor Robert E. Ireland at the University of Virginia as a Swiss NSF postdoctoral fellow, and, in 1990, the University of Pittsburgh as an Assistant Professor. Since 2004, he is the Distinguished University Professor of Chemistry at the University of Pittsburgh. Wipf's research focuses on the total synthesis of natural products, organometallic, heterocyclic and medicinal chemistry. 


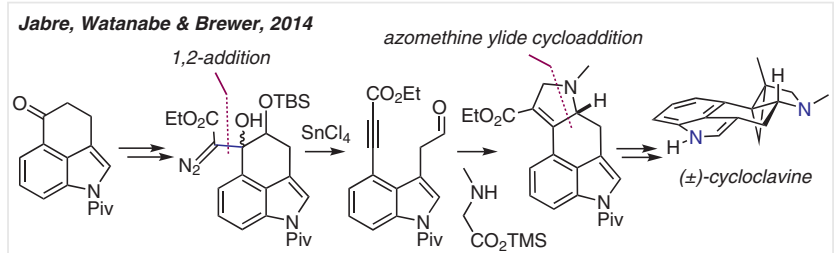

Cao et al., 2014, 2017, 2018

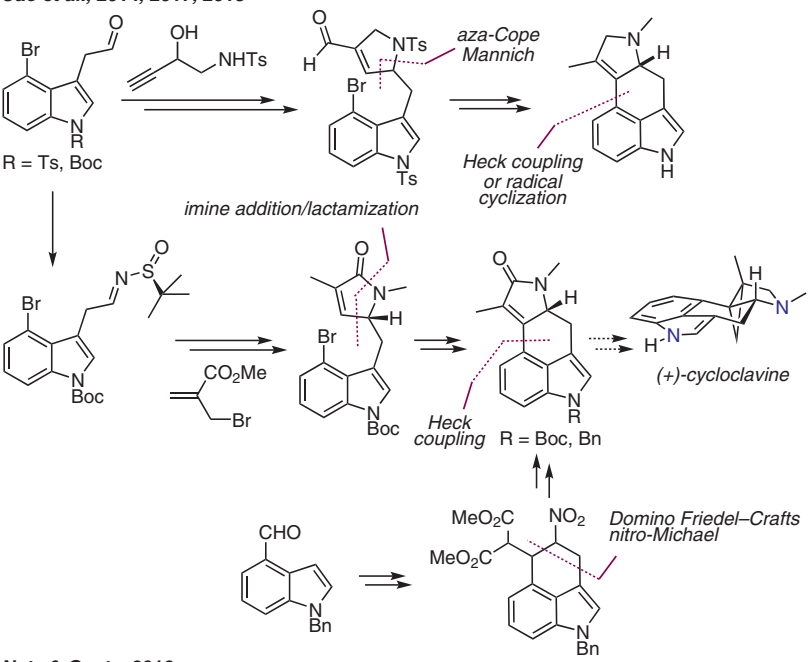

Netz \& Opatz, 2016

McCabe \& Wipf, 2017
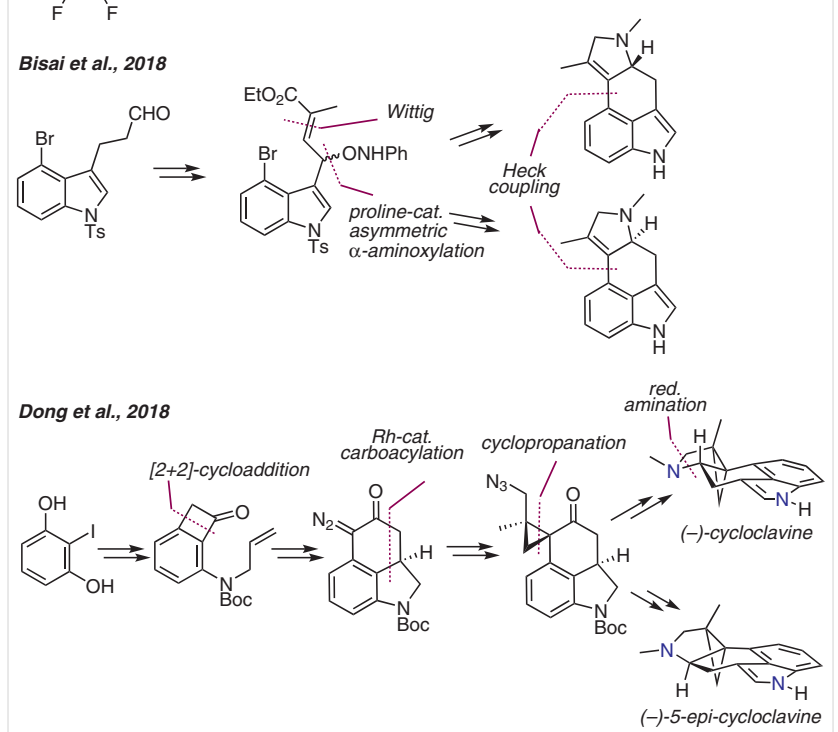

Scheme 2 Recent formal and total syntheses of cycloclavines

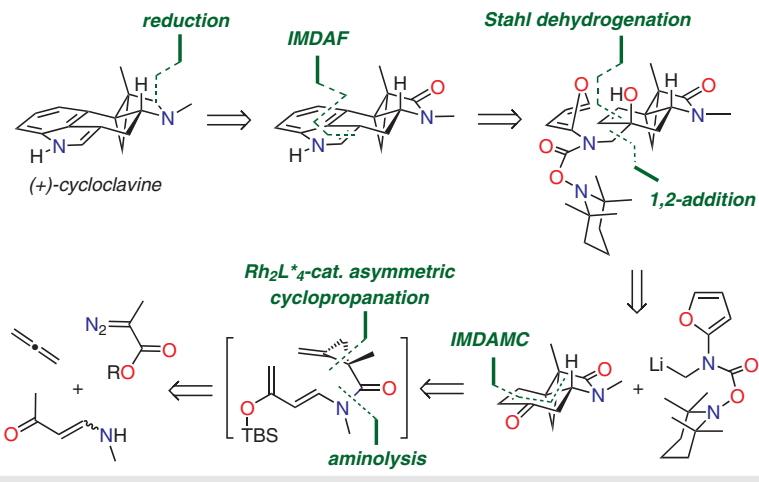

Scheme 3 Retrosynthetic analysis of (+)-cycloclavine

For the realization of this retrosynthetic plan, two building blocks and a chiral ligand needed to be prepared and optimized at the onset of the synthesis. The condensation of pyruvic acid (2) with tosyl hydrazide (1) under acidic conditions provided hydrazone $\mathbf{3}$ in 93\% yield (Scheme 4 ). Treatment with oxalyl chloride and esterification of the resulting acid chloride with pentafluorophenol ( $\mathrm{PfOH})$ delivered an active ester intermediate suitable for rapid segment assembly. Base-mediated diazo formation produced the first building block 4 in $21 \%$ yield.

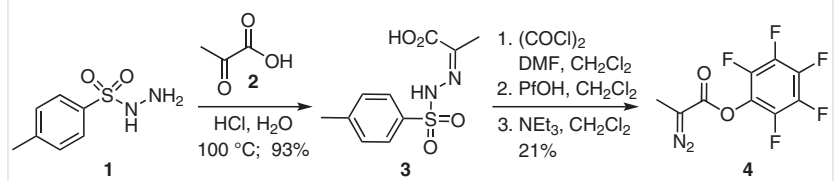

Scheme 4 Preparation of pentafluorophenyl diazoester 4

Next, we focused on the selection of an appropriate transition metal catalyst and chiral ligand for the asymmetric allene cyclopropanation step. Diazopropanoates $\mathbf{5}$ are challenging reagents for use in metal-mediated cyclopropanations because of the propensity of the metal carbenoid 6 to undergo competing $\beta$-hydride migration to form an acrylic ester $\mathbf{7}$ (Scheme 5). In the past decade, several methods have emerged that address this limitation. Fox et al. found that dirhodium complexes with sterically hindered carboxylate ligands in conjunction with low reaction temperatures effectively promoted intermolecular cyclopropanations over the competing $\beta-\mathrm{H}$ migration pathway. ${ }^{17}$

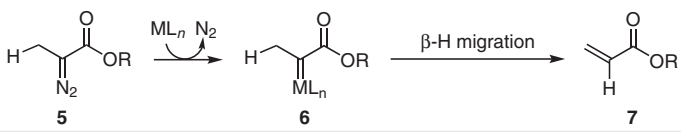

Scheme 5 Competing $\beta$-hydride migration pathway

Among the enantioselective variants, bulky carboxylates derived from L-tert-leucine, such as $\mathrm{Rh}_{2}(\mathrm{~S} \text {-PTTL })_{4}(\mathbf{8})$, were found to be particularly effective. More recently, 
Hashimoto et al. showed that the substrate scope could be further expanded when the dirhodium complex $\mathrm{Rh}_{2}(\mathrm{~S} \text {-TBPTTL })_{4}(\mathbf{9})$ was used as the catalyst (Figure 2$) .{ }^{18} \mathrm{We}$ also prepared the enantiomer of $\mathbf{9}, \mathrm{Rh}_{2}(R \text {-TBPTTL })_{4}(\mathbf{1 0})$, from D-tert-leucine $[(R)-\mathbf{1 8}]$ and anhydride $\mathbf{1 7}$ in toluene at reflux, followed by a ligand exchange reaction with $\mathrm{Rh}_{2}(\mathrm{OAc})_{4}$ in a chlorobenzene/MeCN mixture at $130{ }^{\circ} \mathrm{C}$ (Scheme 6). Furthermore, we reasoned that the 4,7-diphenyl substitution pattern on the phthalimide ring of the novel, sterically demanding dirhodium catalyst $\mathbf{1 1}$ would impose even greater steric discrimination than the corresponding bromide substituents in $\mathbf{9}$ and 10, hopefully leading to greater differentiation between the enantiotopic faces of the allene. This catalyst was prepared in a DielsAlder reaction of diphenylbutadiene (19) and maleic anhydride (20), followed by DDQ oxidation to afford anhydride $\mathbf{2 1}$, which was reacted with $(S)$-18 in the presence of triethylamine to give $\mathbf{2 2}$ and subjected to a ligand exchange reaction to yield $\mathbf{1 1}$ (Scheme 7).

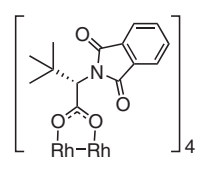

$\mathrm{Rh}_{2}(\mathrm{~S}-\mathrm{PTTL})_{4}(\mathbf{8})$

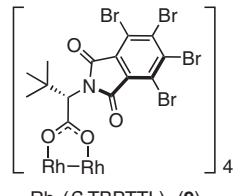

$\mathrm{Rh}_{2}(\mathrm{~S} \text {-TBPTTL })_{4}(9)$

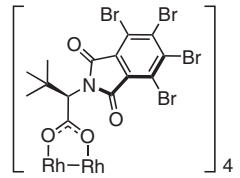

$\mathrm{Rh}_{2}(R-\mathrm{TBPTTL})_{4}(\mathbf{1 0})$

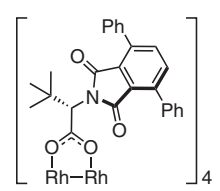

$\mathrm{Rh}_{2}(\mathrm{~S} \text {-DPPTTL })_{4}(\mathbf{1 1})$

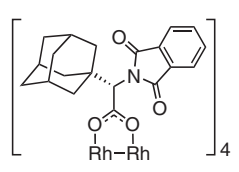

$\mathrm{Rh}_{2}(\mathrm{~S}-\mathrm{PTAD})_{4}(\mathbf{1 2})$

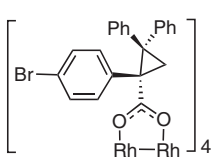

13

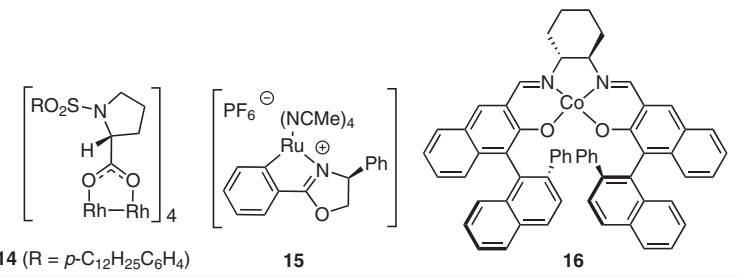

Figure 2 Cyclopropanation catalysts

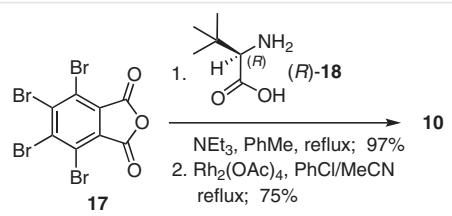

Scheme 6 Preparation of chiral dirhodium catalyst 10

For further comparisons of ligand chemotypes, we decided to include an evaluation of the known dirhodium catalysts 12-14 (Figure 2). ${ }^{19}$ The ruthenium(II) complex 15 was added to this list because $\mathbf{1 5}$ was highly effective in related asymmetric cyclopropanations of mono- and disub-

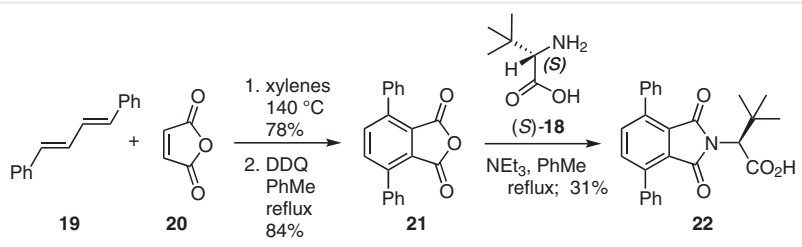

$\mathrm{Rh}_{2}(\mathrm{OAc})_{4}, \mathrm{PhCl}$

reflux; $48 \%$

Scheme 7 Preparation of chiral dirhodium catalyst 11

stituted allenes with succinimidyl diazoacetate. ${ }^{20}$ Finally, the (salen)cobalt(II) catalyst $\mathbf{1 6}$ was also screened since Katsuki et al. showed that it was an excellent catalyst for the enantioselective cyclopropanation of styrenes with $\alpha$-alkyldiazoacetates. ${ }^{21}$

The results of the cyclopropanation of allene (23) with pentafluorophenyl diazopropanoate (4) to give methylenecyclopropane $\mathbf{2 4}$ in the presence of the chiral catalysts 8-16 are summarized in Table 1. Rh(II)-Catalysts with sterically hindered amino acid ligands but lacking phthalimide substituents, such as $\mathbf{8}$ and 12, provided a low e.r. of approximately 7:3 (Table 1, entries 1 and 5). Hashimoto's tetrabromophthaloyl tert-leucine dirhodium catalyst 9 resulted in a notable improvement, giving the cyclopropane $(R)-24$ in a high yield with an e.r. of 87:13 (entry 2). As expected, the $(R)$-tert-leucine derived $\mathbf{1 0}$ gave the enantiomeric product (S)-24 in identical yield and e.r. (entry 3 ). Disappointingly, however, virtually no enantioinduction was observed when allene was reacted with $\mathbf{4}$ in the presence of the sterically more demanding dirhodium catalyst 11 (product e.r. = 55:45, entry 4). With this catalyst, no reaction occurred at $-78{ }^{\circ} \mathrm{C}$ and the mixture had to be warmed to $-40{ }^{\circ} \mathrm{C}$ before conversion was observed. The chiral cyclopropane catalyst $\mathbf{1 3}$ delivered the desired product 24 in moderate yields and with poor enantioinduction (entry 6). Davies' proline-based catalyst $\mathbf{1 4}$ also provided only a moderate yield of $61 \%$, and negligible asymmetric induction (entry 7). The reaction of Ru(II)-catalyst $\mathbf{1 5}$ did not deliver any of the desired product. Instead, upon warming the reaction mixture from $-78{ }^{\circ} \mathrm{C}$ to room temperature, full conversion into the undesired $\beta-\mathrm{H}$ migration product $\mathbf{2 5}$ was observed (entry 8). Similarly, the (salen)cobalt(II) catalyst 16 showed no catalytic activity even at room temperature (entry 9).

In our synthetic route, the cyclopropanation of allene (23) with diazopropanoate 4 in the presence of $1 \mathrm{~mol} \%$ of the dirhodium catalyst $\mathrm{Rh}_{2}(R \text {-TBPTTL })_{4}(\mathbf{1 0})$ provided the enantiomerically enriched methylenecyclopropane $(S)-\mathbf{2 4}$ on multi-gram scale. Ester aminolysis with the lithium salt of $\mathbf{2 6}$ gave the vinylogous imide $\mathbf{2 7}$ in 80\% yield and 87:13 e.r. (Scheme 8). Deprotonation of $\mathbf{2 7}$ with NaHMDS in THF at -78 to $-50{ }^{\circ} \mathrm{C}$ formed the corresponding sodium enolate, which was trapped with TBSCl to give the silyl enol ether intermediate 28. When heated at $95{ }^{\circ} \mathrm{C}$ in THF in the micro- 
Table 1 Catalytic Asymmetric Cyclopropanation of Allene: Catalyst Screen

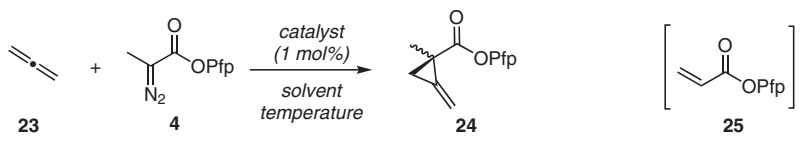

\begin{tabular}{|c|c|c|c|c|c|c|c|}
\hline Entry & Catalyst & Temperature & Solvent & Major product & Yield (\%) & e.r. ${ }^{a}$ & $\begin{array}{l}\text { Major } \\
\text { enantiomer }\end{array}$ \\
\hline 1 & 8 & $-78^{\circ} \mathrm{C}$ & hexanes & 24 & 83 & $72: 28$ & $R$ \\
\hline 2 & 9 & $-78{ }^{\circ} \mathrm{C}$ & $\mathrm{CH}_{2} \mathrm{Cl}_{2}$ & 24 & 86 & $87: 13$ & $R$ \\
\hline 3 & 10 & $-78^{\circ} \mathrm{C}$ & $\mathrm{CH}_{2} \mathrm{Cl}_{2}$ & 24 & 86 & $87: 13$ & $S$ \\
\hline 4 & 11 & $-78^{\circ} \mathrm{C}$ to $-40^{\circ} \mathrm{C}$ & $\mathrm{CH}_{2} \mathrm{Cl}_{2}$ & 24 & 78 & $55: 45$ & $R$ \\
\hline 5 & 12 & $-78{ }^{\circ} \mathrm{C}$ & hexanes & 24 & 84 & $73: 27$ & $R$ \\
\hline 6 & 13 & $-78^{\circ} \mathrm{C}$ & $\mathrm{CH}_{2} \mathrm{Cl}_{2}$ & 24 & 59 & $59: 41$ & $R$ \\
\hline 7 & 14 & $-78^{\circ} \mathrm{C}$ & hexanes & 24 & 61 & $53: 47$ & $R$ \\
\hline 8 & 15 & $-78^{\circ} \mathrm{C}$ to r.t. & $\mathrm{CH}_{2} \mathrm{Cl}_{2}$ & 25 & $N D^{b}$ & - & - \\
\hline 9 & $16^{c}$ & $-78{ }^{\circ} \mathrm{C}$ to r.t. & THF & - & - & - & - \\
\hline
\end{tabular}

a Enantiomeric ratios were determined by chiral SFC analysis of the corresponding imide $\mathbf{2 7}$.

${ }^{\mathrm{b}} \mathrm{ND}$ : Not determined.

c 10 mol\% $N$-methylimidazole was added.

wave reactor, this diene underwent the intramolecular strain-promoted Diels-Alder (IMDAMC) reaction, and TBAF cleavage of the product silyl enol ether formed the desired trans-adduct $\mathbf{3 0}$ in 66\% yield along with the cis-adduct $\mathbf{2 9}$ in $15 \%$ yield. These two diastereomers were readily separated chromatographically. Dehydrogenation of $\mathbf{3 0}$ under modified Diao-Stahl conditions ${ }^{14}$ with $\mathrm{Pd}(\mathrm{TFA})_{2}$ and DMSO in $\mathrm{AcOH}$ under an atmosphere of oxygen at $55^{\circ} \mathrm{C}$ gave the corresponding enone $\mathbf{3 1}$ in $66 \%$ yield as a single regioisomer. Interestingly, dehydrogenation of the epimer $\mathbf{2 9}$ under these conditions provided the opposite enone regioisomer 32 stereospecifically in 56\% yield. This complete switch in regioselectivity for the cis- and trans-diastereomers $\mathbf{2 9}$ and 30 parallels results obtained for the enolization of cis- and trans-2-decalones. ${ }^{22}$ The configuration at the decalin ring junction governs the regioselectivity of enolization process due to torsional strain effects. The torsional strain that was proposed to govern the regiochemistry of enolization in cisand trans-decalones has also been investigated in greater detail in relevant cis- and trans-octalins. ${ }^{22 \mathrm{~b}, 23}$

Enone 31 was obtained as a crystalline solid, and its enantiomeric ratio could be further enriched by recrystallization from 87:13 to yield product with $>99 \%$ e.r. Chiral SFC analysis was used to evaluate each batch for enantiomeric purity.

For the completion of the total synthesis, stannane 34 was treated with $n$-BuLi at low temperature and converted into the corresponding lithium carbanion (Scheme 9). Addition of enone $\mathbf{3 1}$ to the reaction mixture delivered two diastereomeric allylic alcohols, which could be separated by chromatography on silica gel to give $\alpha$-alcohol $\alpha-35$ and $\beta$ -

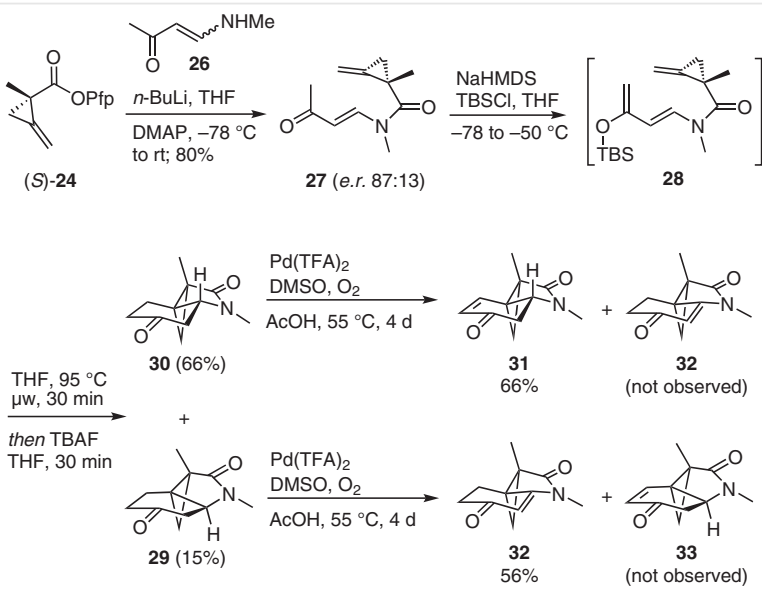

Scheme 8 Segment condensation, IMDAMC reaction, and dehydrogenation

alcohol $\beta$-35 in $41 \%$ and $32 \%$ yield, respectively. The intramolecular Diels-Alder (IMDAF) reaction of $\alpha$-35 (bearing a pseudo-equatorial hydroxy group) at $135{ }^{\circ} \mathrm{C}$ in a sealed tube was followed by spontaneous aromatization and cleavage of the Tempoc protecting group under the reaction conditions to form indole $\mathbf{3 6}$. The stereoisomeric alcohol $\beta$-35 was inert under these conditions, quite likely due to steric strain in the transition state that requires a pseudo-axial position of the substituent bearing the furan ring. Finally, lactam reduction led to (+)-cycloclavine in 34\% yield over two steps from $\alpha-35$. Overall, the synthesis of the natural enantiomer was accomplished in 8 steps and $4 \%$ yield. The specific rotation of the synthetic material was determined 
to be $+61.4\left(c 0.2, \mathrm{CHCl}_{3}\right)$, which was consistent with the literature value $+63\left(c 1, \mathrm{CHCl}_{3}\right) .{ }^{4}$ Mass spectra, $\mathrm{IR},{ }^{1} \mathrm{H}$, and ${ }^{13} \mathrm{C}$ NMR data were also consistent with the previously reported data for the natural product as well as its enantiomer. ${ }^{4,11}$
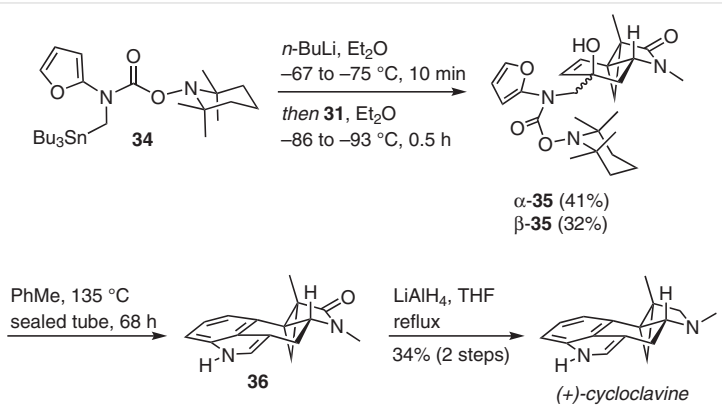

Scheme 9 Completion of total synthesis of (+)-cycloclavine

In contrast to the vast literature on lysergic acid derivatives, relatively little is known about the pharmaceutical potential of clavine ergot alkaloids. ${ }^{2 b}$ Lysergic acid derivatives, most notably lysergic acid diethylamide (LSD) have significant hallucinogenic properties that can interfere with their therapeutic potential. Most of these effects are thought to be mediated through agonist action at the 5-hydroxytryptamine receptor $2 \mathrm{~A}, 5-\mathrm{HT}_{2 \mathrm{~A}}$. In the tailwind of the rapidly expanding medical uses of cannabinoids, the mush- room metabolite psilocybin, and even LSD, are now moving to the forefront of clinical research on the management of mental health, anxiety, neurodegeneration, and substanceuse disorders. ${ }^{24}$ It would appear that more fundamental research on efficacy, tolerability, and safety of serotonergic psychedelics is highly warranted.

It is well known that binding of lysergic acid derivatives to brain membrane receptors is stereospecific, since L-LSD, the psychotropically inactive enantiomer of LSD, is ca. 1000 times weaker as a brain membrane receptor radioligand displacing agent, ${ }^{25}$ and L-LSD as well as the other diastereomers, D-iso-lysergic acid diethylamide (iso-LSD) and L-isolysergic acid diethylamide (L-iso-LSD), show no psychic effects in humans up to a dose of $0.5 \mathrm{mg}$, which corresponds to a 20-fold increase over a still distinctly active D-LSD dose. ${ }^{26}$ Having gained ready synthetic access to both natural (+)-cycloclavine and its unnatural enantiomer (-)-cycloclavine, ${ }^{11}$ we were therefore interested to determine the receptor profiles of both compounds, and compare them to other serotonergic agents.

For an initial survey, we selected 13 pertinent CNS receptors and profiled both enantiomers at $10 \mu \mathrm{M}$ concentration (Table 2). Compound binding was calculated as a percent inhibition of a radioactively labeled ligand specific for each target. As a group, the cycloclavines were more selective in this receptor panel than D-LSD, ${ }^{27,28}$ the bioactive LSD stereoisomer. D-LSD was active at the adrenergic $\alpha_{1}$ and histamine $\mathrm{H}_{1}$ receptors (Table 2, entries 1 and 6), whereas both

Table 2 Effects of Cycloclavines and D-LSD Expressed as Percent Inhibition (\% Inh.) of Specific Binding of a Radioligand Standard to Selected CNS Receptors $^{\mathrm{a}}$

\begin{tabular}{|c|c|c|c|c|c|c|}
\hline Entry & Receptor & (+)-Cycloclavine [10 $\mu \mathrm{M}]$ & (+)-Cycloclavine $[1 \mu \mathrm{M}]$ & (-)-Cycloclavine $[10 \mu \mathrm{M}]$ & (-)-Cycloclavine $[1 \mu \mathrm{M}]$ & D-LSD $[10 \mu \mathrm{M}]^{\mathrm{b}}$ \\
\hline $1^{\mathrm{c}}$ & Adrenergic $\alpha_{1}$ & 57 & & 59 & & $100^{\mathrm{d}}$ \\
\hline 2 & Dopamine $\mathrm{D}_{1}$ & 91 & & 30 & & 93 \\
\hline 3 & Dopamine $\mathrm{D}_{2 \mathrm{~L}}$ & 81 & & 14 & & 85 \\
\hline 4 & Dopamine $\mathrm{D}_{3}$ & 93 & 75 & 64 & 32 & 78 \\
\hline $5^{c}$ & $\mathrm{GABA}_{\mathrm{A}}$ & 9 & & 0 & & 0 \\
\hline 6 & Histamine $\mathrm{H}_{1}$ & 17 & & 27 & & $85^{c}$ \\
\hline 7 & Muscarinic $\mathrm{M}_{2}$ & 0 & & 0 & & 2 \\
\hline 8 & Muscarinic $\mathrm{M}_{5}$ & 11 & & 15 & & 15 \\
\hline 9 & Nicotinic acetylcholine $\alpha 4 \beta 2$ & 9 & & 11 & & 0 \\
\hline 10 & Opiate $\kappa$ & 73 & & 75 & & 29 \\
\hline 11 & Orexin $\mathrm{OX}_{1}$ & 23 & & 6 & & $N D^{e}$ \\
\hline 12 & Serotonin $5-\mathrm{HT}_{1 \mathrm{~A}}$ & 97 & 97 & 91 & 73 & 100 \\
\hline 13 & Serotonin $5-\mathrm{HT}_{2 \mathrm{~A}}$ & 100 & 100 & 89 & 51 & 93 \\
\hline
\end{tabular}

a Biochemical assays were performed in duplicate at human receptors at Eurofins Cerep Panlabs and are presented as the percent inhibition of specific binding or activity of a radioligand, unless otherwise indicated.

b Data from ref. 27.

' Rat receptor data.

${ }^{\mathrm{d}}$ Data from ref. 28.

e ND: Not determined. 
cycloclavines were moderately active at the opiate $\kappa$ receptor (entry 10). Neither ergot chemotype showed significant activity at $\mathrm{GABA}_{\mathrm{A}}$, muscarinic $\mathrm{M}_{2}$ and $\mathrm{M}_{5}$, and nicotinic acetyl-choline $\alpha 4 \beta 2$ receptors (entries $5,7,8$, and 9 ). We were unable to find LSD data on orexin $\mathrm{OX}_{1}$, but cycloclavine did not perturb radioligand binding at this site at a $10 \mu \mathrm{M}$ concentration (entry 11 ).

Significant differences between (+)- and (-)-cycloclavine revealed themselves in the dopamine $\mathrm{D}_{1}, \mathrm{D}_{2 \mathrm{~L}}$, and $\mathrm{D}_{3}$ monoamine receptor family (Table 2 , entries $2-4$ ). In close analogy to D-LSD, natural (+)-cycloclavine maintained strong affinity to these receptors, which stimulate cognitive and motor functions. (-)-Cycloclavine showed comparatively moderate activity at the dopamine $\mathrm{D}_{3}$ receptor at 10 $\mu \mathrm{M}$ concentration, but fell below the threshold of $50 \%$ inhibition at $1 \mu \mathrm{M}$, whereas (+)-cycloclavine still maintained significant binding at this concentration (entry 4). A less prominent but still distinctive stereospecificity was observed at the serotonin $5-\mathrm{HT}_{1 \mathrm{~A}}$ and $5-\mathrm{HT}_{2 \mathrm{~A}}$ receptors (entries 12 and 13). Natural (+)-cycloclavine had very potent binding properties at both 10 and $1 \mu \mathrm{M}$, whereas (-)-cycloclavine tailed off at $1 \mu \mathrm{M}$. Serotonin receptors regulate a plethora of behavioral responses, from aggression, anxiety, appetite, to learning, memory, sleep, and even aging. ${ }^{29} \mathrm{D}-$ LSD is one of the most potent agonists at $5-\mathrm{HT}_{\mathrm{A}}$, and the affinity at the $5-\mathrm{HT}_{\mathrm{A} 2}$ and possibly the $5-\mathrm{HT}_{2 \mathrm{C}}$ receptors versus the $5-\mathrm{HT}_{1 \mathrm{~A}}$ receptor correlates with the mental effects of psychedelics in humans. ${ }^{30}$ In view of this interesting stereospecificity, and the significance of 5-HT receptors to human behavior, we decided to pursue additional studies on 5-HT subtypes (Table 3 ).

The purpose of our second generation functional assays on human 5-HT receptors was to determine effective concentrations $\mathrm{EC}_{50}$ or inhibitory constants $\left(\mathrm{K}_{i}\right)$ for $(+)$-cycloclavine and (-)-cycloclavine. Cellular agonist effects were calculated as a percentage of a control response to a validated reference for each target, and cellular antagonist effect was calculated as percent inhibition of a validated control agonist response for each target. In addition to D-LSD, we selected $\mathrm{N}, \mathrm{N}$-dimethyltryptamine (DMT) and psilocin as two relevant reference compounds. ${ }^{31,32}$ DMT is the only known endogenous $\mathrm{N}, \mathrm{N}$-dimethylated trace amine in mammals, and a prominent component in the sacramental tea ayahuasca. ${ }^{33}$ Its psychopharmacology has recently been compared to so-called 'near-death experiences'. ${ }^{34}$ Psilocin is the pharmacologically active agent after ingestion of the prodrug psilocybin present in some species of psychedelic mushrooms. Psilocybin is currently clinically investigated as a treatment for anxiety and depression in cancer care, as well as for enhancement of cognitive flexibility and creativity. ${ }^{35}$

As suggested by the preliminary assays, (+)-cycloclavine provided considerably more potent at the $5-\mathrm{HT}_{1 \mathrm{~A}}$ receptor than (-)-cycloclavine with an activation potency $\mathrm{EC}_{50}=0.14$ $\mu \mathrm{M}$ versus $\sim 5 \mu \mathrm{M}$ for (-)-cycloclavine (Table 3 , entry 1 ). Both stereoisomers are poor activators at $5-\mathrm{HT}_{2 \mathrm{~A}}$, suggesting that hallucinogenic or strongly euphoric effects in humans might be limited in comparison to D-LSD, even though (+)-cycloclavine displays its most potent activation potential $\mathrm{EC}_{50}=16 \mathrm{nM}$ at $5-\mathrm{HT}_{2 \mathrm{C}}$, a receptor that is thought to contribute to the observed mental effects of psychedelic drugs (entries 2 and 4). With the exception of DMT, which has only moderate potency, none of the tested agents activated $5-\mathrm{HT}_{2 \mathrm{~B}}$, a $5-\mathrm{HT}$ receptor subtype that has been associated with cardiotoxicity. Overall, the 5-HT profile of (+)-cycloclavine closely mirrors that of psilocin, and to a lesser extent, that of DMT. It is substantially different from D-LSD, a property that we believe bodes well for future therapeutic investigations of this compound class.

The unusual activity on the opioid $\kappa$ receptor, and the relative similarity to psilocin and DMT in the 5-HT panel inspired us to also evaluate the activity of cycloclavines in the sigma-1 assay, a receptor that was originally mischaracterized as an opioid receptor and has now been implicated in neuroinflammation and neuroprotection. ${ }^{36}$ DMT was identified as an endogenous sigma- 1 receptor regulator. ${ }^{33,37}$ Surprisingly, while (+)-cycloclavine was inactive, the unnatural (-)-cycloclavine was determined to have a $\mathrm{K}_{i}=8.3 \mu \mathrm{M}$ for

Table 3 Effects of Cycloclavines, DMT, Psilocin, and D-LSD on 5-HT Subtypes and Sigma-1 Receptors ${ }^{\mathrm{a}, \mathrm{b}}$

\begin{tabular}{|c|c|c|c|c|c|c|}
\hline Entry & Receptor & $(+)$-Cycloclavine $[\mu \mathrm{M}]$ & (-)-Cycloclavine $[\mu \mathrm{M}]$ & $\mathrm{DMT}^{\mathrm{c}}[\mu \mathrm{M}]$ & Psilocin ${ }^{\mathrm{C}}[\mu \mathrm{M}]$ & $\mathrm{D}-\mathrm{LSD}^{\mathrm{C}}[\mu \mathrm{M}]$ \\
\hline 1 & Serotonin $5-\mathrm{HT}_{1 \mathrm{~A}}$ & 0.14 & $\sim 5$ & $0.075^{d}$ & $0.123^{d}$ & $0.003^{d}$ \\
\hline 2 & Serotonin $5-\mathrm{HT}_{2 \mathrm{~A}}$ & $\sim 10$ & $>50$ & 0.076 & 0.721 & 0.261 \\
\hline 3 & Serotonin $5-\mathrm{HT}_{2 B}$ & $>20$ & $>20$ & 3.4 & $>20$ & 12 \\
\hline 4 & Serotonin $5-\mathrm{HT}_{2 \mathrm{C}}$ & 0.016 & 3.2 & $0.424^{d}$ & $0.094^{\mathrm{d}}$ & $0.015^{d}$ \\
\hline $5^{d}$ & Sigma-1 & $\sim 50$ & 8.3 & $5.2^{\mathrm{e}}$ & $>10^{\mathrm{e}}$ & $N D^{f}$ \\
\hline
\end{tabular}

a Biochemical assays were performed in duplicate at human receptors at Eurofins Cerep Panlabs and results are based on 5-point concentration response curves, unless otherwise indicated.

${ }^{\mathrm{b}}$ Activation potency $\mathrm{EC}_{50}$ values are shown, unless otherwise specified.

'Data from ref. 31, unless otherwise specified.

d Inhibition constants $\mathrm{K}$

e Data from ref. 32.

${ }^{\mathrm{f}} \mathrm{ND}$ : Not determined. 
the inhibition of the binding of the radiolabeled agonist haloperidol to sigma-1, and therefore found to be very similar to DMT $\left(K_{i}=5.2 \mu \mathrm{M}\right)$ (Table 3, entry 5). To the best of our knowledge, this is the first time that stereospecific binding of ergot alkaloids to a sigma receptor has been observed, and, accordingly, it is feasible to consider (-)-cycloclavine as a potential lead structure for sigma receptor modulator design.

In conclusion, we have successfully completed a total synthesis of natural (+)-cycloclavine, featuring an optimization of the catalyst for the asymmetric cyclopropanation of allene with an active ester diazopropanoate, a regiospecific Pd-catalyzed ketone dehydrogenation to the enone, and two intramolecular Diels-Alder reactions for indole/indoline annulations. Furthermore, we have characterized the binding effects of (+)- and (-)-cycloclavine against 16 CNS receptors, and discovered significant stereospecificity properties. (+)-Cycloclavine has at least 10 -fold higher potency at the serotonin $5-\mathrm{HT}_{2 \mathrm{C}}$ receptor than at any of the other tested receptors, making it one of the most selective tryptamines discovered to date. Furthermore, the receptor subtype profile of $(+)$-cycloclavine resembles that of the clinically validated mushroom metabolite psilocin more closely than the related psychedelics LSD and DMT. Finally, we determined that the unnatural (-)-cycloclavine has considerably lower affinities at all 5-HT receptors than (+)-cycloclavine, but is quite active at the sigma- 1 receptor, a property that it shares with the endogenous sigma- 1 ligand DMT. We suggest that these results, in combination with the excellent synthetic tractability of the cycloclavine scaffold, encourage future research on the medicinal chemistry of clavine alkaloids.

All glassware were dried in an oven at $140{ }^{\circ} \mathrm{C}$ for at least $2 \mathrm{~h}$ prior to use. All air and moisture-sensitive reactions were performed under a dry $\mathrm{N}_{2}$ atmosphere. Reactions carried out at $0{ }^{\circ} \mathrm{C}$ employed an ice bath and reactions carried out at $-78^{\circ} \mathrm{C}$ employed a dry ice/acetone bath. THF and $\mathrm{Et}_{2} \mathrm{O}$ were distilled over $\mathrm{Na} /$ benzophenone ketyl; $\mathrm{Et}_{3} \mathrm{~N}$, $\mathrm{CH}_{2} \mathrm{Cl}_{2}$, and toluene were distilled from $\mathrm{CaH}_{2}$. All other materials were obtained from commercial sources and used as received. Microwave reactions were performed using a Biotage Initiator or an Anton Paar Monowave 300 reactor in glass microwave vials (cap sealed) with continuous magnetic stirring and internal ruby thermometer and/or external infrared surface temperature sensor. IR spectra were obtained from neat solids or oils on ATR FT-IR spectrophotometers. Melting points were determined in open capillary tubes and are uncorrected. High-resolution mass spectra were obtained on a Q-TOF MS or a Thermo Scientific Exactive Orbitrap LC-MS. ${ }^{1} \mathrm{H}$ and ${ }^{13} \mathrm{C}$ NMR spectra were obtained at $300,400,500,600$, or $700 \mathrm{MHz}$ NMR in $\mathrm{CDCl}_{3}$, unless otherwise specified. ${ }^{13} \mathrm{C}$ NMR spectra were obtained at 100,125 , or $150 \mathrm{MHz}$ with proton-decoupling. Chemical shifts $(\delta)$ are reported in parts per million with the residual solvent peak used as an internal standard: ${ }^{1} \mathrm{H} /{ }^{13} \mathrm{C}$ (Solvent) $\delta=7.26 / 77.16\left(\mathrm{CDCl}_{3}\right)$; 7.16/128.06 $\left(\mathrm{C}_{6} \mathrm{D}_{6}\right), 5.32 / 54.00\left(\mathrm{CD}_{2} \mathrm{Cl}_{2}\right)$, and 2.08/20.43 (toluene- $\left.d_{8}\right)$ and are tabulated as follows: chemical shift, multiplicity (standard abbreviations), and coupling constant(s), number of protons. Reac- tions were monitored by TLC analysis (pre-coated silica gel 60 F254 plates, $250 \mu \mathrm{m}$ layer thickness) and visualization was accomplished with a $\mathrm{KMnO}_{4}$ solution $\left(1.50 \mathrm{~g}\right.$ of $\mathrm{KMnO}_{4}, 10 \mathrm{~g}$ of $\mathrm{K}_{2} \mathrm{CO}_{3}$, and $1.25 \mathrm{~mL}$ of $10 \% \mathrm{NaOH}$ in $200 \mathrm{~mL}$ of $\mathrm{H}_{2} \mathrm{O}$ ), when needed. Flash chromatography was performed using $\mathrm{SiO}_{2}(40-63 \mu \mathrm{m})$. Specific rotations were measured on a polarimeter equipped with a sodium lamp. Pentafluorophenyl 2-diazopropanoate (4) $)^{11}$ and stannane $\mathbf{3 4}{ }^{11}$ were prepared as reported previously.

\section{$N$-Tetrabromophthaloyl-(R)-tert-leucine}

An oven-dried flask topped with a Dean-Stark apparatus and condenser was charged sequentially with $(R)$-tert-leucine $[(R)-\mathbf{1 8} ; 0.500$ $\mathrm{g}, 3.77 \mathrm{mmol})$, tetrabromophthalic anhydride $(\mathbf{1 7} ; 1.79 \mathrm{~g}, 3.77 \mathrm{mmol})$, anhyd toluene $(10 \mathrm{~mL})$, and $\mathrm{NEt}_{3}(0.0536 \mathrm{~mL}, 0.377 \mathrm{mmol})$. The resulting heterogeneous mixture was heated at reflux while the solvent was removed at a rate of ca. $1 \mathrm{~mL} / \mathrm{h}$. The solution was cooled to r.t. and treated with aq $5 \% \mathrm{HCl}(6 \mathrm{~mL})$ and EtOAc $(15 \mathrm{~mL})$. The aqueous layer was extracted with EtOAc $(6 \mathrm{~mL})$ and the combined organic layers were dried $\left(\mathrm{Na}_{2} \mathrm{SO}_{4}\right)$ and concentrated to give $\mathrm{N}$-tetrabromophthaloyl- $(R)$-tert-leucine as a white solid; yield: $2.11 \mathrm{~g}(97 \%) ;[\alpha]_{\mathrm{D}}{ }^{20}$ +22.3 (c 0.40, EtOH).

${ }^{1} \mathrm{H}$ NMR (300 MHz, acetone- $\left.d_{6}\right): \delta=4.68(\mathrm{~s}, 1 \mathrm{H}), 1.19(\mathrm{~s}, 9 \mathrm{H})$.

The experimental data were consistent with the literature-reported data for the enantiomer. ${ }^{18}$

\section{Dirhodium(II) Tetrakis[ $N$-tetrabromophthaloyl-(R)-tert-leuci- nate] $\left[R h_{2}(R-T B P T T L){ }_{4}, 10\right]$}

An oven dried flask topped with a Dean-Stark apparatus and condenser was charged with $\mathrm{Rh}_{2}(\mathrm{OAc})_{4}(0.130 \mathrm{~g}, 0.294 \mathrm{mmol}), \mathrm{N}$-tetrabromophthaloyl- $(R)$-tert-leucine $(0.933 \mathrm{~g}, 1.62 \mathrm{mmol})$, and a mixture of chlorobenzene and $\mathrm{MeCN}(9: 1,13 \mathrm{~mL})$. The resulting dark purple solution was heated at reflux while the solvent was removed at a rate of ca. $1 \mathrm{~mL} /$ h over $5 \mathrm{~h}$, during which time the solution turned emerald green. After $5 \mathrm{~h}$, the reaction mixture was cooled to r.t. and treated sequentially with toluene $(40 \mathrm{~mL})$ and sat. aq $\mathrm{NaHCO}_{3}(40 \mathrm{~mL})$. The organic layer was washed with $\mathrm{NaHCO}_{3}(40 \mathrm{~mL})$, brine $(40 \mathrm{~mL})$, filtered, and dried $\left(\mathrm{Na}_{2} \mathrm{SO}_{4}\right)$ to provide $\mathbf{1 0}(0.555 \mathrm{~g}, 75 \%)$ as a green solid, which was used directly without further purification.

${ }^{1} \mathrm{H}$ NMR (300 MHz, benzene- $\left.d_{6}\right): \delta=5.37(\mathrm{~s}, 4 \mathrm{H}), 1.45(\mathrm{~s}, 36 \mathrm{H})$.

The experimental data were consistent with the literature-reported data for the enantiomer. ${ }^{38}$

\section{4,7-Diphenyl-3a,4,7,7a-tetrahydroisobenzofuran-1,3-dione}

A clear, yellow solution of butadiene 19 ( $2.0 \mathrm{~g}, 9.6 \mathrm{mmol})$ and maleic anhydride 20 (1.1 g, $11 \mathrm{mmol})$ in xylenes $(25 \mathrm{~mL})$ was heated at 140 ${ }^{\circ} \mathrm{C}$ for $16 \mathrm{~h}$. After this time, the reaction was cooled to $0{ }^{\circ} \mathrm{C}$ and the resulting precipitate was filtered to afford the Diels-Alder adduct as a white solid; yield: $2.29 \mathrm{~g}$ (78\%).

${ }^{1} \mathrm{H}$ NMR (500 MHz, $\mathrm{CDCl}_{3}$ ): $\delta=7.43$ (app t, $J=7.3 \mathrm{~Hz}, 4 \mathrm{H}$ ), 7.39-7.36 $(\mathrm{m}, 6 \mathrm{H}), 6.56(\mathrm{~s}, 2 \mathrm{H}), 3.84(\mathrm{~d}, J=4.0 \mathrm{~Hz}, 2 \mathrm{H}), 3.74(\mathrm{dd}, J=4.5,2.0 \mathrm{~Hz}$, $2 \mathrm{H})$.

The experimental data were consistent with the literature-reported data. $^{39}$

\section{4,7-Diphenylisobenzofuran-1,3-dione (21)}

A red solution of 4,7-diphenyl-3a,4,7,7a-tetrahydroisobenzofuran1,3-dione (1.0 g, $3.3 \mathrm{mmol})$ and DDQ ( $1.5 \mathrm{~g}, 6.6 \mathrm{mmol})$ in toluene (10 $\mathrm{mL}$ ) was heated at $110{ }^{\circ} \mathrm{C}$ for $17 \mathrm{~h}$. The reaction mixture was concen- 
trated and filtered, and the solid was washed with EtOH to provide crude $21(0.832 \mathrm{~g}, 84 \%)$ as a light pink solid that was used without further purification.

${ }^{1} \mathrm{H}$ NMR $\left(300 \mathrm{MHz}, \mathrm{CDCl}_{3}\right): \delta=7.85(\mathrm{~s}, 2 \mathrm{H}), 7.61-7.57(\mathrm{~m}, 4 \mathrm{H}), 7.54-$ $7.51(\mathrm{~m}, 6 \mathrm{H})$.

The experimental data were consistent with the literature-reported data. $^{39}$

\section{(S)-2-(1,3-Dioxo-4,7-diphenylisoindolin-2-yl)-3,3-dimethylbuta-} noic Acid (22)

An oven-dried microwave vial was charged sequentially with 4,7-diphenylisobenzofuran-1,3-dione $(\mathbf{2 1} ; 0.300 \mathrm{~g}, 1.00 \mathrm{mmol}),(S)$-tertleucine $(0.199 \mathrm{~g}, 1.50 \mathrm{mmol})$, and $\mathrm{NEt}_{3}(0.0283 \mathrm{~mL}, 0.200 \mathrm{mmol})$, and the resulting heterogeneous brown solution was heated at reflux for $19 \mathrm{~h}$. The solution was cooled to r.t., and extracted with aq $5 \% \mathrm{HCl}$ and EtOAc. The aqueous layer was back-extracted with EtOAc $(3 \times)$, and the combined organic layers were dried $\left(\mathrm{Na}_{2} \mathrm{SO}_{4}\right)$, filtered, and concentrated. The resulting residue was purified by chromatography on $\mathrm{SiO}_{2}\left(0-20 \%\right.$ acetone $\left./ \mathrm{CH}_{2} \mathrm{Cl}_{2}\right)$ to provide the carboxylic acid 22 as a white foam; yield: $0.128 \mathrm{~g}(31 \%) ; \mathrm{mp} 142.7-145{ }^{\circ} \mathrm{C}$; $[\alpha]_{\mathrm{D}}{ }^{19}-10.6(\mathrm{c}$ $\left.0.17, \mathrm{CHCl}_{3}\right)$

IR (ATR): 2963, 1770, 1710, 1603, 1475, 1382, 1122, 903, 752, $698 \mathrm{~cm}^{-1}$. ${ }^{1} \mathrm{H}$ NMR $\left(300 \mathrm{MHz}, \mathrm{CDCl}_{3}\right): \delta=7.67(\mathrm{~s}, 2 \mathrm{H}), 7.56$ (app dd, $J=7.6,1.9$ $\mathrm{Hz}, 4 \mathrm{H}), 7.52-7.45$ (m, $6 \mathrm{H}), 4.68$ (s, $1 \mathrm{H}), 1.14$ (s, $9 \mathrm{H})$.

${ }^{13} \mathrm{C}$ NMR $\left(100 \mathrm{MHz}, \mathrm{CDCl}_{3}\right): \delta=172.3,167.3,140.4,136.5,136.3$, 129.6, 128.9, 128.3, 128.1, 60.0, 35.8, 28.2.

HRMS (LCMS ESI+): $\mathrm{m} / z$ calcd for $\mathrm{C}_{26} \mathrm{H}_{24} \mathrm{NO}_{4}(\mathrm{M}+\mathrm{H})^{+}$: 414.1700; found: 414.1698 .

\section{Tetrakis-(S)-2-(1,3-dioxo-4,7-diphenylisoindolin-2-yl)-3,3-di-} methylbutanoic Acid Dirhodium(II) Complex (11)

A microwave vial was charged with (S)-2-(1,3-dioxo-4,7-diphenylisoindolin-2-yl)-3,3-dimethylbutanoic acid (22; $0.090 \mathrm{~g}, 0.22 \mathrm{mmol})$, $\mathrm{Rh}_{2}(\mathrm{OAc})_{4}(0.016 \mathrm{~g}, 0.036 \mathrm{mmol})$, and chlorobenzene $(0.5 \mathrm{~mL})$, and the resulting green solution was heated overnight at $145{ }^{\circ} \mathrm{C}$ (external temperature, oil bath). The reaction mixture was cooled and concentrated. The resulting green residue was purified by chromatography on $\mathrm{SiO}_{2}\left(0-2 \%\right.$ acetone $\left./ \mathrm{CH}_{2} \mathrm{Cl}_{2}\right)$ to deliver a green residue, which was dissolved in EtOAc and concentrated to provide the bis-EtOAc adduct of $\mathbf{1 1}$ as an emerald green crystalline solid; yield: $36 \mathrm{mg}$ (48\%); mp $280-282.9^{\circ} \mathrm{C}$ (dec.); $[\alpha]_{D}{ }^{20}+217\left(\right.$ c $\left.0.03, \mathrm{CHCl}_{3}\right)$.

IR (ATR): 2944, 1716, 1606, 1509, 1353, 1226, 1046, $737 \mathrm{~cm}^{-1}$.

${ }^{1} \mathrm{H}$ NMR (500 MHz, $\mathrm{CDCl}_{3}$ ): $\delta=7.52$ (br s, $\left.8 \mathrm{H}\right), 7.44-7.33(\mathrm{~m}, 40 \mathrm{H}$ ), 4.20 (s, $4 \mathrm{H}$ ), 4.12 (q, J = 7.3 Hz, 4 H, EtOAc), 2.04 (s, 6 H, EtOAc), 1.23 $(\mathrm{t}, J=7.0 \mathrm{~Hz}, 6 \mathrm{H}, \mathrm{EtOAc}), 0.84(\mathrm{~s}, 36 \mathrm{H})$.

${ }^{13} \mathrm{C}$ NMR (125 MHz, $\mathrm{CDCl}_{3}$ ): $\delta=187.4(8 \mathrm{C}), 171.9$ (4 C), $166.3(4 \mathrm{C})$, 166.1 (4 C), 140.0 (4 C), 139.3 (4 C), 136.8 (8 C), 136.3 (4 C), 135.3 (4 C), 129.9 (8 C), 128.2 (16 C), 127.8 (16 C), 60.7 (EtOAC), 60.6 (4 C), 35.6 (4 C), 28.2 (12 C), 21.2 (EtOAc), 14.3 (EtOAc).

HRMS (ESI+): $m / z$ calcd for $\mathrm{C}_{104} \mathrm{H}_{89} \mathrm{~N}_{4} \mathrm{O}_{16} \mathrm{Rh}_{2}(\mathrm{M}+\mathrm{H})^{+}:$1855.4378; found: 1855.4318

\section{Asymmetric Cyclopropanation of Allene; General Procedure (Table 1)}

Pentafluorophenyl (R)-1-Methyl-2-methylenecyclopropane-1carboxylate $[(\boldsymbol{R})-24)]^{11}$

An oven-dried three-necked flask was charged with the respective catalyst $(0.0056 \mathrm{mmol})$ and hexanes or $\mathrm{CH}_{2} \mathrm{Cl}_{2}(2.8 \mathrm{~mL})$, and the resulting green solution was cooled to $-78{ }^{\circ} \mathrm{C}$ and treated dropwise with an excess of condensed gaseous allene (23; ca. $14 \mathrm{mmol}$ ). The reaction mixture was then treated with a solution of pentafluorophenyl 2-diazopropanoate $(4 ; 0.56 \mathrm{mmol})$ in hexanes or $\mathrm{CH}_{2} \mathrm{Cl}_{2}(1.7 \mathrm{~mL})$ via syringe pump at a rate of $1 \mathrm{~mL} / \mathrm{h}$. After the addition was complete, the mixture was allowed to warm to r.t. The solution was concentrated under reduced pressure and the resulting residue was purified by chromatography on $\mathrm{SiO}_{2}\left(0-2 \% \mathrm{Et}_{2} \mathrm{O} /\right.$ hexanes $)$ to provide methylenecyclopropane $(R)-\mathbf{2 4}$.

${ }^{1} \mathrm{H}$ NMR $\left(400 \mathrm{MHz}, \mathrm{CD}_{2} \mathrm{Cl}_{2}\right): \delta=5.64(\mathrm{t}, J=2.8 \mathrm{~Hz}, 1 \mathrm{H}), 5.56(\mathrm{t}, J=2.2$ $\mathrm{Hz}, 1 \mathrm{H}), 2.30$ (dt, $J=9.2,2.5 \mathrm{~Hz}, 1 \mathrm{H}), 1.63(\mathrm{dt}, J=9.2,2.4 \mathrm{~Hz}, 1 \mathrm{H})$, $1.51(\mathrm{~s}, 3 \mathrm{H})$.

(R,E)-N,1-Dimethyl-2-methylene- $N$-(3-oxobut-1-en-1-yl)cyclopropane-1-carboxamide $[(R)-27]^{11}$

An oven-dried flask charged with vinylogous amide $\mathbf{2 6}^{7}(0.0178 \mathrm{~g}$, $0.18 \mathrm{mmol}, 1.0$ equiv) was evacuated and backfilled with $\mathrm{N}_{2}(3 \times$ ). Freshly distilled THF $(0.6 \mathrm{~mL})$ was added and the resulting solution was cooled to $-78{ }^{\circ} \mathrm{C}$ and treated dropwise with $n$-BuLi (2.29 M solution in hexanes, $0.082 \mathrm{~mL}, 0.19 \mathrm{mmol}, 1.05$ equiv). The resulting clear, pale yellow solution was stirred for $5 \mathrm{~min}$ at $-78^{\circ} \mathrm{C}$, then treated with a solution of ester $(R)-\mathbf{2 4}(0.053 \mathrm{~g}, 0.19 \mathrm{mmol}, 1.05$ equiv) in THF (1 $\mathrm{mL}$ ). The resulting bright yellow solution was treated with DMAP ( $0.023 \mathrm{~g}, 0.19 \mathrm{mmol}, 0.1$ equiv) and stirred for $10 \mathrm{~min}$ at $-78{ }^{\circ} \mathrm{C}$. The cold bath was removed and the reaction mixture was allowed to warm to r.t. The reaction was quenched with sat. aq $\mathrm{NaHCO}_{3}$. After addition of EtOAc, the aqueous layer was extracted with EtOAc $(3 \times)$ and the combined organic layers were dried $\left(\mathrm{Na}_{2} \mathrm{SO}_{4}\right)$ and concentrated. The crude product was purified by chromatography on $\mathrm{SiO}_{2}(10-$ $15 \% \mathrm{EtOAc} /$ hexanes) to provide vinylogous imide $(R)-27$ as a clear, pale yellow oil; yield: $28 \mathrm{mg}$ ( $80 \%$ ).

${ }^{1} \mathrm{H}$ NMR $\left(300 \mathrm{MHz}, \mathrm{CDCl}_{3}\right): \delta=8.36(\mathrm{~d}, J=13.8 \mathrm{~Hz}, 1 \mathrm{H}), 5.71(\mathrm{~d}, J=$ $13.8 \mathrm{~Hz}, 1 \mathrm{H}$ ), 5.69 (app t, $J=3.0 \mathrm{~Hz}, 1 \mathrm{H}), 5.53$ (app s, $1 \mathrm{H}), 3.15(\mathrm{~s}, 3$ H), $2.29(\mathrm{~s}, 3 \mathrm{H}), 1.79(\mathrm{dt}, J=9.6,2.2 \mathrm{~Hz}, 1 \mathrm{H}), 1.49(\mathrm{~s}, 3 \mathrm{H}), 1.32(\mathrm{dt}, J=$ 9.6, $2.2 \mathrm{~Hz}, 1 \mathrm{H})$.

SFC conditions for e.r. analysis: Chiralpak-IC semi-prep column $(250 \times$ $10 \mathrm{~mm}$ ), gradient elution: 5-15\% $i$-PrOH, $7 \mathrm{~mL} / \mathrm{min}, 254 \mathrm{~nm}$ detection, $P=100$ bar

Pentafluorophenyl (S)-1-Methyl-2-methylenecyclopropane-1-carboxylate $[(S)-24]$ (Table1, entry 3$)$

An oven-dried three-necked flask fitted with a $\mathrm{N}_{2}$ inlet, a dry-ice condenser, and a septum was charged with $\mathrm{Rh}_{2}(R \text {-TBPTTL })_{4}(\mathbf{1 0} ; 0.566 \mathrm{~g}$, $0.226 \mathrm{mmol}$ ) and $\mathrm{CH}_{2} \mathrm{Cl}_{2}(141 \mathrm{~mL})$, and the green solution was cooled to $-78{ }^{\circ} \mathrm{C}$ (dry ice/acetone bath) and treated dropwise with an excess of condensed gaseous allene (23; ca. 65 drops, $5.14 \mathrm{~g}, 5.52 \mathrm{mmol}$ ). The resulting solution was then treated with a solution of perfluorophenyl 2-diazopropanoate (4; $6.00 \mathrm{~g}, 22.6 \mathrm{mmol})$ in $\mathrm{CH}_{2} \mathrm{Cl}_{2}(12 \mathrm{~mL})$ via syringe pump at a rate of ca. $2 \mathrm{~mL} / \mathrm{h}$. The reaction mixture was allowed to stir at $-78{ }^{\circ} \mathrm{C}$ for $1 \mathrm{~h}$ before warming to r.t. The resulting green residue was purified by chromatography on $\mathrm{SiO}_{2}(0-1 \%$ $\mathrm{Et}_{2} \mathrm{O} /$ hexanes) to afford methylenecyclopropane ( $(S)-\mathbf{2 4}$ as a clear and pale yellow oil; yield: $5.41 \mathrm{~g}(86 \%) ;[\alpha]_{D}{ }^{19}+2.8\left(c 7.6, \mathrm{CHCl}_{3}\right)$. 
${ }^{1} \mathrm{H}$ NMR $\left(500 \mathrm{MHz}, \mathrm{CD}_{2} \mathrm{Cl}_{2}\right): \delta=5.64($ app t, $J=2.8 \mathrm{~Hz}, 1 \mathrm{H}$ ), 5.56 (app $\mathrm{t}, J=2.3 \mathrm{~Hz}, 1 \mathrm{H}), 2.30(\mathrm{dt}, J=9.5,2.5 \mathrm{~Hz}, 1 \mathrm{H}), 1.63(\mathrm{dt}, J=9.2,2.4 \mathrm{~Hz}$, $1 \mathrm{H}), 1.51(\mathrm{~s}, 3 \mathrm{H})$.

HRMS (ESI+): $m / z$ calcd for $\mathrm{C}_{12} \mathrm{H}_{8} \mathrm{~F}_{5} \mathrm{O}_{2}(\mathrm{M}+\mathrm{H})^{+}$: 279.0439; found: 279.0450 .

All other experimental data were consistent with the reported data for the enantiomer. ${ }^{11}$

(S,E)-N,1-Dimethyl-2-methylene- $N$-(3-oxobut-1-en-1-yl)cyclopropane-1-carboxamide [(S)-27]

An oven-dried round bottomed flask was charged with vinylogous amide $\mathbf{2 6}^{7}$ ( $2.77 \mathrm{~g}, 27.9 \mathrm{mmol}$ ) and evacuated and backfilled with $\mathrm{N}_{2}$ $(3 \times)$. Distilled THF $(93 \mathrm{~mL})$ was added and the resulting solution was cooled to $-78{ }^{\circ} \mathrm{C}$ and treated dropwise with $n$-BuLi $(11.7 \mathrm{~mL}, 2.5 \mathrm{M}$ solution in hexanes, $29.3 \mathrm{mmol}$ ). The mixture was stirred for $5 \mathrm{~min}$ at $-78{ }^{\circ} \mathrm{C}$, then treated dropwise with a solution of pentafluorophenyl (S)-1-methyl-2-methylenecyclopropane-1-carboxylate [(S)-24; 8.15 $\mathrm{g}, 29.3 \mathrm{mmol}$ ] in THF $(15 \mathrm{~mL})$. The reaction mixture was treated with DMAP $(0.0341 \mathrm{~g}, 0.279 \mathrm{mmol})$ and stirred for $10 \mathrm{~min}$ at $-78{ }^{\circ} \mathrm{C}$. The cold bath was removed and the solution was allowed to warm to r.t., and quenched with sat. aq $\mathrm{NaHCO}_{3}$ and EtOAc. The aqueous layer was extracted with EtOAc $(3 \times)$ and the combined organic layers were dried $\left(\mathrm{Na}_{2} \mathrm{SO}_{4}\right)$ and concentrated. The crude product was purified by chromatography on $\mathrm{SiO}_{2}$ (10-15\% EtOAc/hexanes) to afford [(S)-27]; yield: $4.30 \mathrm{~g}(80 \%)$; e.r. $87: 13$ by SFC analysis) as a clear and pale yellow oil; $[\alpha]_{D}{ }^{19}-243.2$ ( c 2.24, $\mathrm{CHCl}_{3}$ ).

$\left.{ }^{1} \mathrm{H} \mathrm{NMR} \mathrm{(500} \mathrm{MHz,} \mathrm{CDCl}_{3}\right): \delta=8.37(\mathrm{~d}, J=14.0 \mathrm{~Hz}, 1 \mathrm{H}), 5.73(\mathrm{~d}, J=$ $13.5 \mathrm{~Hz}, 1 \mathrm{H}$ ), 5.71 (app t, $J=2.8 \mathrm{~Hz}, 1 \mathrm{H}), 5.53(\mathrm{~s}, 1 \mathrm{H}), 3.15(\mathrm{~s}, 3 \mathrm{H})$, $2.29(\mathrm{~s}, 3 \mathrm{H}), 1.80(\mathrm{dt}, J=9.8,2.4 \mathrm{~Hz}, 1 \mathrm{H}), 1.50(\mathrm{~s}, 3 \mathrm{H}), 1.33(\mathrm{dt}, J=9.7$, $2.4 \mathrm{~Hz}, 1 \mathrm{H})$.

HRMS (ESI+): $m / z$ calcd for $\mathrm{C}_{11} \mathrm{H}_{16} \mathrm{NO}_{2}(\mathrm{M}+\mathrm{H})^{+}:$194.1176; found: 194.1175.

(1aS,3aR,7aR)-1a,3-Dimethylhexahydro-2H-cyclopropa[c]indole2,5(3H)-dione (30) and (1aS,3aS,7aR)-1a,3-Dimethylhexahydro2H-cyclopropa[c]indole-2,5(3H)-dione (29)

An oven-dried flask was charged with NaHMDS (2.50 g, $12.9 \mathrm{mmol}$ ) and anhyd THF $(150 \mathrm{~mL})$ under an atmosphere of $\mathrm{N}_{2}$. The resulting clear and colorless solution was stirred for $15 \mathrm{~min}$ at r.t., then cooled to $-78^{\circ} \mathrm{C}$, and stirred for a further $15 \mathrm{~min}$ at this temperature prior to treatment with a solution of $\mathbf{2 7}(2.75 \mathrm{~g}, 14.2 \mathrm{mmol})$ in THF $(20 \mathrm{~mL})$ slowly at a rate of ca. $4 \mathrm{~mL} / \mathrm{h}$, maintaining the temperature of the acetone/dry ice bath below $-50{ }^{\circ} \mathrm{C}$. During the slow addition of the amide, the solution changed color from clear and pale yellow to clear and orange. The resulting clear, orange solution was allowed to warm to $-50{ }^{\circ} \mathrm{C}$ over $1 \mathrm{~h}$, cooled to $-78{ }^{\circ} \mathrm{C}$ and treated dropwise with a solution of TBSCl $(2.36 \mathrm{~g}, 15.5 \mathrm{mmol})$ in THF $(52 \mathrm{~mL})$. The reaction mixture was allowed to stir for a further $5 \mathrm{~min}$ at $-78{ }^{\circ} \mathrm{C}$ before the cold bath was removed, and the solution allowed to reach r.t.

${ }^{1} \mathrm{H}$ NMR analysis of an aliquot $\left(\mathrm{CDCl}_{3}\right)$ indicated conversion into enol ether 28.

${ }^{1} \mathrm{H}$ NMR $\left(300 \mathrm{MHz}, \mathrm{CDCl}_{3}\right): \delta=7.65(\mathrm{~d}, J=13.5 \mathrm{~Hz}, 1 \mathrm{H}), 5.67$ (app s, 1 H), $5.52(\mathrm{~d}, J=13.8 \mathrm{~Hz}, 1 \mathrm{H}), 5.45($ app s, $1 \mathrm{H}), 4.23(\mathrm{~s}, 2 \mathrm{H}), 3.13$ (br s, $3 \mathrm{H}), 1.73$ (dt, J = 9.6, $2.1 \mathrm{~Hz}, 1 \mathrm{H}), 1.47(\mathrm{~s}, 3 \mathrm{H}), 1.25$ (dt, $J=9.4,2.2 \mathrm{~Hz}$, $1 \mathrm{H}), 1.00(\mathrm{~s}, 9 \mathrm{H}), 0.25(\mathrm{~s}, 3 \mathrm{H}), 0.24(\mathrm{~s}, 3 \mathrm{H})$.

The mixture was concentrated and directly subjected without purification to the next reaction. A solution of crude amide $\mathbf{2 8}$ (assumed $3.98 \mathrm{~g}, 12.9 \mathrm{mmol})$ in THF ( $28 \mathrm{~mL}, 3.5 \mathrm{~mL} \times 8$ batches) was heated under microwave irradiation at $95{ }^{\circ} \mathrm{C}$ for $30 \mathrm{~min}$, then concentrated to deliver the crude Diels-Alder adducts (assumed $3.98 \mathrm{~g}, 12.9 \mathrm{mmol}$ ) as an orange oil that was used directly in the next conversion. The crude enol ether adducts (assumed $3.98 \mathrm{~g}, 12.9 \mathrm{mmol}$ ) were immediately dissolved in THF $(130 \mathrm{~mL})$, treated dropwise with TBAF $(12.9 \mathrm{~mL}, 1 \mathrm{M}$ solution in THF, $12.9 \mathrm{mmol}$ ) and stirred at r.t. for $30 \mathrm{~min}$. The reaction mixture was filtered through a pad of Florisil (washed with EtOAc) and concentrated. The resulting residue was purified by chromatography on $\mathrm{SiO}_{2}$ (20\% EtOAc/hexanes to elute recovered starting material, then $50-70 \%$ EtOAc/hexanes to elute the trans-diastereomer 30, then 90-100\% EtOAc/hexanes to elute the cis-diastereomer 29) to provide trans-ketone $\mathbf{3 0}$ as a pale yellow solid (1.64 g, 66\%) and cis-ketone $\mathbf{2 9}$ as a yellow oil $(0.371 \mathrm{~g}, 15 \%)$.

\section{0}

$[\alpha]_{\mathrm{D}}{ }^{19}-104.3\left(\right.$ c $\left.0.93 \mathrm{CHCl}_{3}\right)$.

${ }^{1} \mathrm{H}$ NMR $\left(400 \mathrm{MHz}, \mathrm{CDCl}_{3}\right): \delta=3.41(\mathrm{dd}, J=12.8,4.0 \mathrm{~Hz}, 1 \mathrm{H}), 2.80$ (ddd, $J=13.6,4.0,1.6 \mathrm{~Hz}, 1 \mathrm{H}$ ), 2.69 (ddt, $J=15.5,4.8,1.6 \mathrm{~Hz}, 1 \mathrm{H}$ ), 2.66 (s, $3 \mathrm{H}$ ), 2.54 (ddd, $J=15.4,12.2,7.2 \mathrm{~Hz}, 1 \mathrm{H}), 2.35$ (app t, $J=13.4 \mathrm{~Hz}, 1$ H), 2.13 (tdd, $J=12.6,5.0,1.4 \mathrm{~Hz}, 1 \mathrm{H}$ ), 1.72 (ddd, $J=13.1,7.3,1.9 \mathrm{~Hz}$, $1 \mathrm{H}), 1.38(\mathrm{~s}, 3 \mathrm{H}), 0.95(\mathrm{~d}, J=3.6 \mathrm{~Hz}, 1 \mathrm{H}), 0.66(\mathrm{~d}, J=4.0 \mathrm{~Hz}, 1 \mathrm{H})$.

HRMS (ESI+): $m / z$ calcd for $\mathrm{C}_{11} \mathrm{H}_{16} \mathrm{NO}_{2}(\mathrm{M}+\mathrm{H})^{+}$: 194.1176; found: 194.1179.

All other experimental data were consistent with the reported data for the enantiomer. ${ }^{11}$

\section{9}

$[\alpha]_{\mathrm{D}}{ }^{19}+11.0\left(\mathrm{c} 0.15 \mathrm{CHCl}_{3}\right)$.

${ }^{1} \mathrm{H}$ NMR $\left(300 \mathrm{MHz}, \mathrm{CDCl}_{3}\right.$ ): $\delta=3.73($ app t, $J=6.5 \mathrm{~Hz}, 1 \mathrm{H}$ ), 2.84 (dd, $J=$ 15.0, $6.0 \mathrm{~Hz}, 1 \mathrm{H}), 2.72(\mathrm{~s}, 3 \mathrm{H}), 2.53-2.25(\mathrm{~m}, 4 \mathrm{H}), 1.83$ (dt, $J=14.2$, $5.2 \mathrm{~Hz}, 1 \mathrm{H}), 1.34(\mathrm{~s}, 3 \mathrm{H}), 0.93(\mathrm{~d}, J=4.5 \mathrm{~Hz}, 1 \mathrm{H}), 0.84(\mathrm{~d}, J=4.5 \mathrm{~Hz}, 1$ $\mathrm{H})$.

HRMS (ESI+): $m / z$ calcd for $\mathrm{C}_{11} \mathrm{H}_{16} \mathrm{NO}_{2}(\mathrm{M}+\mathrm{H})^{+}:$194.1176; found 194.1178

\section{(1aS,3aR,7aS)-1a,3-Dimethyl-1,1a,3a,4-tetrahydro-2H-cyclopro- pa[c]indole-2,5(3H)-dione (31)}

A solution of Pd(TFA $)_{2}(0.044 \mathrm{~g}, 0.129 \mathrm{mmol})$ and DMSO $(0.018 \mathrm{~mL}$, $0.259 \mathrm{mmol})$ in $\mathrm{AcOH}(13 \mathrm{~mL})$ was heated at $55{ }^{\circ} \mathrm{C}$ under an atmosphere of $\mathrm{O}_{2}$ (balloon). After stirring at $55{ }^{\circ} \mathrm{C}$ overnight, ketone 30 $(0.500 \mathrm{~g}, 2.59 \mathrm{mmol})$ was added and the reaction mixture was allowed to stir at $55^{\circ} \mathrm{C}$ for 4 days. Additional Pd(TFA $)_{2}(2 \times 0.11 \mathrm{~g})$ was added after 24 and $48 \mathrm{~h}$ to drive the reaction to completion. The mixture was concentrated and purified by chromatography on $\mathrm{SiO}_{2}(50-$ $70 \% \mathrm{EtOAc} /$ hexanes) to deliver enone $\mathbf{3 1}$ as a pale yellow solid; yield: $0.32 \mathrm{~g}(66 \%)$.

\section{Enantiomeric Enrichment by Recrystallization of Enone 31; Typi- cal Procedure}

Enone 31 ( $0.110 \mathrm{~g}, 0.573 \mathrm{mmol}$ ) was dissolved in boiling MTBE (9.5 $\mathrm{mL})$ and 1,2-dichloroethane $(0.4 \mathrm{~mL})$ and the solution was allowed to cool to r.t., and kept overnight at $-20{ }^{\circ} \mathrm{C}$. The mother liquor was removed via pipette transfer and the white needle-shaped crystals were washed with MTBE $(2 \times)$ and placed under vacuum to remove trace solvents. The first recrystallization provided compound of $>99.5: 0.5$ e.r. by chiral SFC analysis; a 95.4:4.6 e.r. was achieved in the second recrystallization, and the third recrystallization led to $98: 2$ e.r. to deliver a combined yield of enone 31 ( $0.0654 \mathrm{~g}, 60 \%, 69 \%$ of theoretical maximum) as a white crystalline solid. Only combined samples with e.r. $>97.5: 2.5$ were carried on in the subsequent reaction; $[\alpha]_{D}{ }^{17}+$ 111.1 (c $\left.0.484, \mathrm{CHCl}_{3}\right)$. 
${ }^{1} \mathrm{H}$ NMR $\left(400 \mathrm{MHz}, \mathrm{CDCl}_{3}\right): \delta=6.98(\mathrm{~d}, J=9.6 \mathrm{~Hz}, 1 \mathrm{H}), 6.15(\mathrm{~d}, J=9.6$ $\mathrm{Hz}, 1 \mathrm{H}), 3.82$ (dd, $J=14.2 .3 .8 \mathrm{~Hz}, 1 \mathrm{H}), 2.91(\mathrm{dd}, J=15.9,3.6 \mathrm{~Hz}, 1 \mathrm{H})$, $2.72(\mathrm{~s}, 3 \mathrm{H}), 2.44(\mathrm{dd}, J=15.6,14.0 \mathrm{~Hz}, 1 \mathrm{H}), 1.47(\mathrm{~s}, 3 \mathrm{H}), 1.34(\mathrm{~d}, J=$ $4.0 \mathrm{~Hz}, 1 \mathrm{H}), 0.86(\mathrm{~d}, J=4.0 \mathrm{~Hz}, 1 \mathrm{H})$.

HRMS (ESI+): $m / z$ calcd for $\mathrm{C}_{11} \mathrm{H}_{14} \mathrm{NO}_{2}(\mathrm{M}+\mathrm{H})^{+}:$192.1019; found: 192.1018.

All other experimental data were consistent with the reported data for the enantiomer. ${ }^{11}$

SFC analysis: Chiralpak-IC semiprep column $(250 \times 10 \mathrm{~mm})$, gradient elution: $1-30 \% i-\mathrm{PrOH}, 5.5 \mathrm{~mL} / \mathrm{min}, 254 \mathrm{~nm}$ detection, $P=100$ bar.

\section{(1aS,7aR)-1a,3-Dimethyl-1,1a,6,7-tetrahydro-2H-cyclopropa[c]in- dole-2,5(3H)-dione (32)}

A microwave flask was charged with Pd(TFA $)_{2}(0.0092 \mathrm{~g}, 0.027 \mathrm{mmol})$. The flask was purged and filled with $\mathrm{O}_{2}$, followed by the addition of DMSO $(1.9 \mu \mathrm{L})$ and $\mathrm{AcOH}(1.3 \mathrm{~mL})$. The resulting brown solution was stirred at $55{ }^{\circ} \mathrm{C}$ under an atmosphere of $\mathrm{O}_{2}$ (balloon) for $20 \mathrm{~h}$ then treated with ketone $29(0.052 \mathrm{~g}, 0.27 \mathrm{mmol})$. After 3 days, ${ }^{1} \mathrm{H}$ NMR analysis of an aliquot $\left(\mathrm{CDCl}_{3}\right)$ indicated exclusive formation of a single regioisomer. The reaction mixture was concentrated and purified by chromatography on $\mathrm{SiO}_{2}$ (50\% EtOAc/hexanes) to deliver vinylogous amide 32 as a white solid; yield: $0.029 \mathrm{~g}$ (56\%).

IR (ATR): 2956, 1732, 1607, 1458, 1241, $1074 \mathrm{~cm}^{-1}$.

${ }^{1} \mathrm{H}$ NMR (300 MHz, $\left.\mathrm{CDCl}_{3}\right): \delta=5.49(\mathrm{~s}, 1 \mathrm{H}), 2.93(\mathrm{~s}, 3 \mathrm{H}), 2.68-2.65$ ( $\mathrm{m}, 1 \mathrm{H}), 2.63(\mathrm{~d}, J=5.0 \mathrm{~Hz}, 1 \mathrm{H}), 2.35(\mathrm{td}, J=12.4,6.8 \mathrm{~Hz}, 1 \mathrm{H}), 1.73$ (ddd, $J=13.0,4.7,2.8 \mathrm{~Hz}, 1 \mathrm{H}), 1.41(\mathrm{~s}, 3 \mathrm{H}), 1.33(\mathrm{~d}, J=4.2 \mathrm{~Hz}, 1 \mathrm{H}$ ), $1.17(\mathrm{~d}, J=4.2 \mathrm{~Hz}, 1 \mathrm{H})$.

${ }^{13} \mathrm{C}$ NMR $\left(100 \mathrm{MHz}, \mathrm{CDCl}_{3}\right): \delta=197.2,177.1,164.4,101.4,36.9,30.1$, 29.9, 29.2, 26.2, 24.5, 10.4 .

HRMS (LCMS ESI+): $m / z$ calcd for $\mathrm{C}_{11} \mathrm{H}_{14} \mathrm{NO}_{2}(\mathrm{M}+\mathrm{H})$ : 192.1019; found: 192.1020 .

All data were consistent with the literature-reported data. ${ }^{7}$

\section{Allylic Alcohols $\alpha-35$ and $\beta-35$}

An oven-dried 3-necked $25 \mathrm{~mL}$ flask fitted with two stoppers and $\mathrm{N}_{2}$ inlet was charged with stannane $34^{11}(0.893 \mathrm{~g}, 1.57 \mathrm{mmol})$ and evacuated under high vacuum, then backfilled with $\mathrm{N}_{2}(3 \times)$. A stopper was exchanged for an internal thermocouple thermometer and anhyd $\mathrm{Et}_{2} \mathrm{O}(5 \mathrm{~mL})$ was added. The clear, pale yellow solution was cooled to $-70.5{ }^{\circ} \mathrm{C}\left(\mathrm{Et}_{2} \mathrm{O} /\right.$ dry ice $)$ and stirred for $10 \mathrm{~min}$, then treated dropwise with $n$-BuLi ( $0.628 \mathrm{~mL}, 2.5 \mathrm{M}$ solution in hexanes, $1.57 \mathrm{mmol})$, during which time the temperature rose to $-67.4^{\circ} \mathrm{C}$. The resulting clear, yellow solution was stirred for $15 \mathrm{~min}$ while the internal temperature was maintained between -67.4 and $-74.5{ }^{\circ} \mathrm{C}$, then cooled to $-93.1{ }^{\circ} \mathrm{C}$ using a liquid $\mathrm{N}_{2} / \mathrm{Et}_{2} \mathrm{O}$ bath, and treated with a solution of enone $\mathbf{3 1}$ $(0.250 \mathrm{~g}, 1.31 \mathrm{mmol})$ in anhyd $\mathrm{THF} / \mathrm{Et}_{2} \mathrm{O} 1: 1(3.5 \mathrm{~mL})$ slowly over 10 min in $0.4 \mathrm{~mL}$ portions. The temperature rose to $-86{ }^{\circ} \mathrm{C}$ during the addition, and the reaction mixture was subsequently stirred for $30 \mathrm{~min}$ below $-90{ }^{\circ} \mathrm{C}$, then for $\mathrm{I} \mathrm{h}$ at $-76{ }^{\circ} \mathrm{C}$. The solution was diluted with EtOAc and quenched with aq $2 \mathrm{M} \mathrm{NH}_{4} \mathrm{Cl}$, maintaining the internal temperature below $-50{ }^{\circ} \mathrm{C}$. The aqueous layer was extracted with EtOAc $(5 \times)$, and the combined organic layers were dried $\left(\mathrm{Na}_{2} \mathrm{SO}_{4}\right)$, and concentrated. The residue was purified by chromatography on $\mathrm{SiO}_{2}$ (gradient elution $5 \%$ acetone $/ \mathrm{CH}_{2} \mathrm{Cl}_{2}$ to elute recovered starting material enone 31 ( $3 \mathrm{mg}$ ), then alcohol $\alpha-\mathbf{3 5}$, then $10 \%$ acetone $/ \mathrm{CH}_{2} \mathrm{Cl}_{2}$ was used to elute alcohol $\beta$-35) to deliver equatorial alcohol $\alpha-35$ $(0.250 \mathrm{~g}, 41 \%)$ and axial alcohol $\beta-35$ (0.196 g, 32\%) as white foams.

\section{a-35}

$[\alpha]_{\mathrm{D}}{ }^{18}+30.1\left(\mathrm{c} 0.2, \mathrm{CHCl}_{3}\right)$.

${ }^{1} \mathrm{H}$ NMR $\left(500 \mathrm{MHz}, \mathrm{C}_{6} \mathrm{D}_{6}\right): \delta=6.81(\mathrm{~d}, J=1.0 \mathrm{~Hz}, 1 \mathrm{H}), 5.98(\mathrm{dd}, J=3.3$, $2.3 \mathrm{~Hz}, 1 \mathrm{H}), 5.89(\mathrm{~d}, J=2.5 \mathrm{~Hz}, 1 \mathrm{H}), 5.43(\mathrm{~d}, J=9.5 \mathrm{~Hz}, 1 \mathrm{H}), 5.36(\mathrm{~d}, J=$ $9.5 \mathrm{~Hz}, 1 \mathrm{H}), 3.74(\mathrm{~d}, J=14.5 \mathrm{~Hz}, 1 \mathrm{H}), 3.54(\mathrm{~d}, J=15.0 \mathrm{~Hz}, 1 \mathrm{H}), 3.30(\mathrm{~s}$, $1 \mathrm{H}$ ), 2.97 (dd, $J=13.3,2.3 \mathrm{~Hz}, 1 \mathrm{H}$ ), 2.53 (s, $3 \mathrm{H}$ ), 2.40 (app t, $J=10.8$ $\mathrm{Hz}, 1 \mathrm{H}), 1.67$ (app t, $J=12.3 \mathrm{~Hz}, 1 \mathrm{H}), 1.54($ app t, $J=13.0 \mathrm{~Hz}, 2 \mathrm{H}$ ), $1.31(\mathrm{~s}, 3 \mathrm{H}), 1.27-1.23(\mathrm{~m}, 9 \mathrm{H}), 1.06(\mathrm{dt}, J=13.5,2.8 \mathrm{~Hz}, 1 \mathrm{H}), 0.93(\mathrm{~s}$, $3 \mathrm{H}), 0.92(\mathrm{~s}, 3 \mathrm{H}), 0.75$ (d J = 3.5 Hz, $1 \mathrm{H}), 0.23$ (d, J = 3.5 Hz, $1 \mathrm{H}$ ).

HRMS (ESI+): $m / z$ calcd for $\mathrm{C}_{26} \mathrm{H}_{38} \mathrm{~N}_{3} \mathrm{O}_{5}(\mathrm{M}+\mathrm{H})^{+}$: 472.2806; found: 472.2810 .

\section{$\beta-35$}

$[\alpha]_{D}{ }^{18}+2.0\left(c 0.3, \mathrm{CHCl}_{3}\right)$.

${ }^{1} \mathrm{H} \mathrm{NMR}\left(300 \mathrm{MHz}, \mathrm{C}_{6} \mathrm{D}_{6}\right): \delta=6.84(\mathrm{dd}, J=1.8,0.9 \mathrm{~Hz}, 1 \mathrm{H}), 6.02(\mathrm{dd}, J=$ $3.2,2.0 \mathrm{~Hz}, 1 \mathrm{H}), 5.86(\mathrm{dd}, J=3.2,0.8 \mathrm{~Hz}, 1 \mathrm{H}), 5.60(\mathrm{~d}, J=9.6 \mathrm{~Hz}, 1 \mathrm{H})$, $5.45(\mathrm{~d}, J=9.6 \mathrm{~Hz}, 1 \mathrm{H}), 3.74($ app s, $2 \mathrm{H}), 3.45(\mathrm{~d}, J=13.2 \mathrm{~Hz}, 1 \mathrm{H}), 3.12$ (app d, $J=9.4 \mathrm{~Hz}, 1 \mathrm{H}), 2.46(\mathrm{~s}, 3 \mathrm{H}), 2.08(\mathrm{~d}, J=13.8 \mathrm{~Hz}, 1 \mathrm{H}), 1.58(\mathrm{t}$, $J=13.0 \mathrm{~Hz}, 3 \mathrm{H}), 1.30-1.23(\mathrm{~m}, 12 \mathrm{H}), 1.08($ app dd, $J=11.5,3.4 \mathrm{~Hz}, 1$ H), 0.93 (app s, $6 \mathrm{H}), 0.76$ (d, $J=3.3 \mathrm{~Hz}, 1 \mathrm{H}), 0.21$ (d, J = 3.6 Hz, $1 \mathrm{H}$ ).

HRMS (ESI+): $m / z$ calcd for $\mathrm{C}_{26} \mathrm{H}_{38} \mathrm{~N}_{3} \mathrm{O}_{5}(\mathrm{M}+\mathrm{H})^{+}$: 472.2806; found: 472.2815 .

\section{(+)-Cycloclavine}

A solution of $\alpha-35(0.128 \mathrm{~g}, 0.272 \mathrm{mmol})$ in anhyd degassed toluene $(10 \mathrm{~mL})$ was heated to $135^{\circ} \mathrm{C}$ in a sealed tube for $90 \mathrm{~h}$. The reaction mixture was concentrated and filtered through a pad of $\mathrm{SiO}_{2}$, washing with $2-5 \%$ acetone $/ \mathrm{CH}_{2} \mathrm{Cl}_{2}$ to provide crude $\mathbf{3 6}(27 \mathrm{mg}, 39 \%)$, which was used directly in the next step.

${ }^{1} \mathrm{H}$ NMR (400 MHz, $\left.\mathrm{CD}_{2} \mathrm{Cl}_{2}\right): \delta=8.14($ br s, $1 \mathrm{H}), 7.21(\mathrm{~d}, J=8.0 \mathrm{~Hz}, 1 \mathrm{H})$, 7.09 (dd, $J=8.0,7.2 \mathrm{~Hz}, 1 \mathrm{H}), 7.02($ app s, $1 \mathrm{H}), 6.80(\mathrm{~d}, J=6.8 \mathrm{~Hz}, 1 \mathrm{H})$, $3.78(\mathrm{dd}, J=11.8,4.2 \mathrm{~Hz}, 1 \mathrm{H}), 3.29(\mathrm{dd}, J=13.6,4.0 \mathrm{~Hz}, 1 \mathrm{H}), 2.79(\mathrm{~s}, 3$ H), 2.71-2.64 (m, $1 \mathrm{H}), 1.80(\mathrm{~s}, 3 \mathrm{H}), 1.14(\mathrm{~d}, J=3.6 \mathrm{~Hz}, 1 \mathrm{H}), 0.84(\mathrm{~d}, J=$ $3.2 \mathrm{~Hz}, 1 \mathrm{H})$.

A microwave vial was charged with a solution of crude $\mathbf{3 6}(0.0270 \mathrm{~g}$, $0.107 \mathrm{mmol})$ in anhyd THF $(1.2 \mathrm{~mL})$ under an atmosphere of $\mathrm{N}_{2}$. The solution was cooled to $0{ }^{\circ} \mathrm{C}$ and treated dropwise with $\mathrm{LiAlH}_{4}(0.535$ $\mathrm{mL}, 1 \mathrm{M}$ solution in $\left.\mathrm{Et}_{2} \mathrm{O}, 0.535 \mathrm{mmol}\right)$. The reaction mixture was stirred at reflux in a sealed tube for $16 \mathrm{~h}$, diluted with $\mathrm{Et}_{2} \mathrm{O}$, cooled to $0{ }^{\circ} \mathrm{C}$ and treated sequentially with $\mathrm{H}_{2} \mathrm{O}(0.020 \mathrm{~mL})$, aq $15 \% \mathrm{NaOH}$ $(0.020 \mathrm{~mL})$ and $\mathrm{H}_{2} \mathrm{O}(0.061 \mathrm{~mL})$, warmed to r.t. and stirred for $15 \mathrm{~min}$. Anhyd $\mathrm{MgSO}_{4}$ was then added and the solution was stirred rigorously for $15 \mathrm{~min}$, and filtered through a pad of Celite. The crude residue was purified by chromatography on $\mathrm{SiO}_{2}$ (pre-washed column with $0.1 \%$ $\mathrm{NEt}_{3} / \mathrm{CH}_{2} \mathrm{Cl}_{2}$, then gradient elution $0-2 \% \mathrm{MeOH} / \mathrm{CH}_{2} \mathrm{Cl}_{2}$ with $0.1 \% \mathrm{NEt}_{3}$ added to each eluent) to deliver (+)-cycloclavine as a white solid; yield: $22.0 \mathrm{mg}$ ( $86 \%$, or $34 \%$ over 2 steps); $\mathrm{mp} 161.1-163.8{ }^{\circ} \mathrm{C}$ (dec.); $[\alpha]_{D}{ }^{18}+61.4\left(c 0.2, \mathrm{CHCl}_{3}\right) ;\left\{\right.$ Lit. $\left.^{4}[\alpha]_{\mathrm{D}}{ }^{20}+63\left(c 1, \mathrm{CHCl}_{3}\right)\right\}$

IR (ATR): 3409, 3166, 3103, 3062, 2942, 2885, 2843, 2788, 1617, 1590, $1442,1322,1165,1095,922,749 \mathrm{~cm}^{-1}$.

${ }^{1} \mathrm{H}$ NMR $\left(500 \mathrm{MHz}, \mathrm{CDCl}_{3}\right): \delta=7.89$ (br s, $\left.1 \mathrm{H}\right), 7.13(\mathrm{dd}, J=8.0,0.5 \mathrm{~Hz}$, $1 \mathrm{H}$ ), 7.09 (app t, $J=7.8 \mathrm{~Hz}, 1 \mathrm{H}$ ), 6.90 (app t, $J=1.8 \mathrm{~Hz}, 1 \mathrm{H}$ ), 6.82 (dd, $J=7.0,0.5 \mathrm{~Hz}, 1 \mathrm{H}), 3.15(\mathrm{~d}, J=9.0 \mathrm{~Hz}, 1 \mathrm{H}), 3.13(\mathrm{dd}, J=13.8,3.8 \mathrm{~Hz}, 1$ $\mathrm{H}), 2.78(\mathrm{dd}, J=11.5,4.0 \mathrm{~Hz}, 1 \mathrm{H}), 2.63-2.57(\mathrm{~m}, 1 \mathrm{H}), 2.40(\mathrm{~d}, J=8.5$ $\mathrm{Hz}, 1 \mathrm{H}), 2.36(\mathrm{~s}, 3 \mathrm{H}), 1.69(\mathrm{~s}, 3 \mathrm{H}), 1.60(\mathrm{~d}, J=3.5 \mathrm{~Hz}, 1 \mathrm{H}), 0.45(\mathrm{~d}, J=$ 3.5 $\mathrm{Hz}, 1 \mathrm{H})$.

${ }^{13} \mathrm{C}$ NMR $\left(150 \mathrm{MHz}, \mathrm{CDCl}_{3}\right): \delta=135.6,133.7,128.8,123.1,118.2$, $113.5,110.5,108.1,69.8,65.7,40.1,34.5,27.9,25.1,24.4,16.6$. 
DEPT-135 (100 MHz, $\left.\mathrm{CDCl}_{3}\right): \delta=123.1(\mathrm{CH}), 118.2(\mathrm{CH}), 110.5(\mathrm{CH})$, $108.1(\mathrm{CH}), 69.8(\mathrm{CH}), 65.8\left(\mathrm{CH}_{2}\right), 40.1\left(\mathrm{NCH}_{3}\right), 25.1\left(\mathrm{CH}_{2}\right), 24.4\left(\mathrm{CH}_{2}\right)$, $16.6\left(\mathrm{CH}_{3}\right)$.

HRMS (LCMS ESI + ): $m / z$ calcd for $\mathrm{C}_{16} \mathrm{H}_{19} \mathrm{~N}_{2}(\mathrm{M}+\mathrm{H})^{+}:$239.1543; found: 239.1544.

All relevant data were consistent with the literature-reported data for the natural product ${ }^{4}$ and the enantiomer. ${ }^{11}$

\section{Funding Information}

The authors are grateful to Boehringer-Ingelheim Pharmaceuticals Inc., Ridgefield CT, for partial financial support of this work. SRM also acknowledges support from the Mary E. Warga and the University of Pittsburgh Arts and Sciences Mellon Fellowships.

\section{Acknowledgment}

The authors thank M. K. Wipf for graphical support.

\section{Supporting Information}

Supporting information for this article is available online at https://doi.org/10.1055/s-0037-1610395. Spectral data $\left({ }^{1} \mathrm{H}\right.$ and ${ }^{13} \mathrm{C}$ NMR for selected new compounds and (+)-cycloclavine).

\section{References}

(1) (a) Hager, A.; Vrielink, N.; Hager, D.; Lefranc, J.; Trauner, D. Nat. Prod. Rep. 2016, 33, 491. (b) Susick, R. B.; Morrill, L. A.; Picazo, E.; Garg, N. K. Synlett 2017, 28, 1. (c) Wang, Y.; Xie, F.; Lin, B.; Cheng, M.; Liu, Y. Chem. Eur. J. 2018, 24, 14302. (d) Xie, X.; Zu, L. Synlett 2018, 29, 1008. (e) Liu, H.; Jia, Y. Nat. Prod. Rep. 2017, 34, 411.

(2) (a) Chadha, N.; Silakari, O. Eur. J. Med. Chem. 2017, 134, 159. (b) Bharate, S. S.; Mignani, S.; Vishwakarma, R. A. J. Med. Chem. 2018, 61, in press; doi.org/10.1021/acs.jmedchem.7b01922. (c) Homer, J. A.; Sperry, J. J. Nat. Prod. 2017, 80, 2178.

(3) McCabe, S. R.; Wipf, P. Org. Biomol. Chem. 2016, 14, 5894.

(4) Stauffacher, D.; Niklaus, P.; Tscherter, H.; Weber, H. P.; Hofmann, A. Tetrahedron 1969, 25, 5879.

(5) Incze, M.; Doernyei, G.; Moldvai, I.; Temesvari-Major, E.; Egyed, O.; Szantay, C. Tetrahedron 2008, 64, 2924.

(6) (a) Pierce, J. G.; Kasi, D.; Fushimi, M.; Cuzzupe, A.; Wipf, P. J. Org. Chem. 2008, 73, 7807. (b) Petronijevic, F.; Timmons, C.; Cuzzupe, A.; Wipf, P. Chem. Commun. 2009, 104. (c) Wang, C.; Widom, J.; Petronijevic, F.; Burnett, J. C.; Nuss, J. E.; Bavari, S.; Gussio, R.; Wipf, P. Heterocycles 2009, 79, 487. (d) LaPorte, M.; Hong, K. B.; Xu, J.; Wipf, P. J. Org. Chem. 2013, 78, 167. (e) Alverez, C.; Arkin, M. R.; Bulfer, S. L.; Colombo, R.; Kovaliov, M.; LaPorte, M. G.; Lim, C.; Liang, M.; Moore, W. J.; Neitz, R. J.; Yan, Y.; Yue, Z.; Huryn, D. M.; Wipf, P. ACS Med. Chem. Lett. 2015, 6, 1225. (f) Xu, J.; Wipf, P. Org. Biomol. Chem. 2017, 15, 7093.

(7) Petronijevic, F. R.; Wipf, P. J. Am. Chem. Soc. 2011, 133, 7704.

(8) Jabre, N. D.; Watanabe, T.; Brewer, M. Tetrahedron Lett. 2014, 55, 197.
(9) (a) Wang, W.; Lu, J.-T.; Zhang, H.-L.; Shi, Z.-F.; Wen, J.; Cao, X.-P. J. Org. Chem. 2014, 79, 122. (b) Chen, J.-Q.; Song, L.-L.; Li, F.-X.; Shi, Z.-F.; Cao, X.-P. Chem. Commun. 2017, 53, 12902. (c) Chen, J.-Q.; Mi, Y.; Shi, Z.-F.; Cao, X.-P. Org. Biomol. Chem. 2018, 16, 3801.

(10) Netz, N.; Opatz, T. J. Org. Chem. 2016, 81, 1723.

(11) McCabe, S. R.; Wipf, P. Angew. Chem. Int. Ed. 2017, 56, 324.

(12) Chaudhuri, S.; Ghosh, S.; Bhunia, S.; Bisai, A. Chem. Commun. 2018, 54, 940.

(13) Deng, L.; Chen, M.; Dong, G. J. Am. Chem. Soc. 2018, 140, 9652.

(14) Diao, T.; Stahl, S. S. J. Am. Chem. Soc. 2011, 133, 14566.

(15) Lizza, J. R.; Bremerich, M.; McCabe, S. R.; Wipf, P. Org. Lett. 2018, 20,6760 .

(16) Padwa, A.; Flick, A. C. Adv. Heterocycl. Chem. 2013, 110, 1.

(17) Panne, P.; DeAngelis, A.; Fox, J. M. Org. Lett. 2008, 10, 2987.

(18) Goto, T.; Takeda, K.; Anada, M.; Ando, K.; Hashimoto, S. Tetrahedron Lett. 2011, 52, 4200.

(19) (a) Davies, H. M. L.; Stafford, D. G.; Doan, B. D.; Houser, J. H. J. Am. Chem. Soc. 1998, 120, 3326. (b) Qin, C.; Boyarskikh, V.; Hansen, J. H.; Hardcastle, K. I.; Musaev, D. G.; Davies, H. M. L. J. Am. Chem. Soc. 2011, 133, 19198. (c) DeAngelis, A.; Dmitrenko, O.; Yap, G. P. A.; Fox, J. M. J. Am. Chem. Soc. 2009, 131, 7230.

(20) Lindsay, V. N. G.; Fiset, D.; Gritsch, P. J.; Azzi, S.; Charette, A. B. J. Am. Chem. Soc. 2013, 135, 1463.

(21) Uchida, T.; Katsuki, T. Synthesis 2006, 1715.

(22) (a) House, H. O.; Trost, B. M. J. Org. Chem. 1965, 30, 1341. (b) Velluz, L.; Valls, J.; Nominé, G. Angew. Chem., Int. Ed. Engl. 1965, 4, 181.

(23) Nasipuri, D. Stereochemistry of Organic Compounds: Principles and Applications; New Age International: New Delhi, 1994.

(24) dos Santos, R. G.; Bouso, J. C.; Alcazar-Corcoles, M. A.; Hallak, J. E. C. Exp. Rev. Clin. Pharm. 2018, 11, 889.

(25) Bennett, J. P. Jr.; Snyder, S. H. Brain Res. 1975, 94, 523.

(26) Hofmann, A. LSD - My Problem Child; McGraw-Hill Book Company: New York, 1980.

(27) Roth, B. L.; Baner, K.; Westkaemper, R.; Siebert, D.; Rice, K. C.; Steinberg, S.; Ernsberger, P.; Rothman, R. B. Proc. Natl. Acad. Sci. U.S.A. 2002, 99, 11934.

(28) Rickli, A.; Luethi, D.; Reinisch, J.; Buchy, D.; Hoener, M. C.; Liechti, M. E. Neuropharmacology 2015, 99, 546.

(29) Nichols, D. E.; Nichols, C. D. Chem. Rev. 2008, 108, 1614.

(30) (a) Glennon, R. A.; Titeler, M.; McKenney, J. D. Life Sci. 1984, 35, 2505. (b) Nichols, C. D.; Sanders-Bush, E. Heffter Rev. Psychedel. Res. 2001, 2, 73. (c) Ref. 24

(31) Rickli, A.; Moning, O. D.; Hoener, M. C.; Liechti, M. E. Eur. Neuropsychopharmacol. 2016, 26, 1327.

(32) Ray, T. S. PLoS One 2010, 5, e9019.

(33) Fontanilla, D.; Johannessen, M.; Hajipour, A. R.; Cozzi, N. V.; Jackson, M. B.; Ruoho, A. E. Science 2009, 323, 934.

(34) Timmermann, C.; Roseman, L.; Williams, L.; Erritzoe, D.; Martial, C.; Cassol, H.; Laureys, S.; Nutt, D.; Carhart-Harris, R. Front. Psych. 2018, 9, 1424.

(35) (a) Nutt, D. J. Psychopharm. 2016, 30, 1163. (b) Prochazkova, L.; Lippelt, D. P.; Colzato, L. S.; Sjoerds, Z.; Kuchar, M.; Hommel, B. Psychopharmacology (Berl) 2018, in press; doi.org/10.1007/s00213-018-5049-7.

(36) Chu, U. B.; Ruoho, A. E. Mol. Pharmacol. 2016, 89, 142.

(37) Szabo, A.; Frecska, E. Neural Regen. Res. 2016, 11, 396.

(38) Goto, T.; Takeda, K.; Shimada, N.; Nambu, H.; Anada, M.; Shiro, M.; Ando, K.; Hashimoto, S. Angew. Chem. Int. Ed. 2011, 50, 6803.

(39) Rainbolt, J. E.; Miller, G. P. J. Org. Chem. 2007, 72, 3020. 